\title{
İlköğretim 4-5-6 ve 7. Sınıf Sosyal Bilgiler Ders Kitaplarında Yer Alan Analojilerin İncelenmesi
}

\author{
Ayşegül ŞEYIHOĞLU* İbrahim Emrah ÖZGÜRBÜZ*** Elif TORUN***
}

- Geliş Tarihi: 24.10.2021 • Kabul Tarihi: 04.02.2022 • Çevrimiçi Yayın Tarihi: 04.02.2022

\section{$\ddot{\mathbf{O} z}$}

Bu çalışmanın amacı 2020-2021 eğitim-öğretim yılı içerisinde ilköğretim 4., 5., 6. ve 7. sınıf seviyesinde kullanılan Sosyal Bilgiler ders kitaplarında yer alan analojileri kullanım düzeyleri ve türlerini incelemektir. Nitel yaklaşımın benimsendiği çalışmada veriler doküman analizi tekniğiyle bir araya getirilmiş ve doküman olarak 4., 5., 6. ve 7. sınıf seviyesindeki Sosyal Bilgiler ders kitapları incelenmiştir. Çalışmada ders kitaplarındaki analojileri tespit etmek için içerik analizi, analojileri türlerine ve öğrenme alanlarına göre sınıflandırmak için betimsel analiz kullanılmış ve bulgular tablolaştırılmıştır. Araştırma sonucunda Sosyal Bilgiler ders kitaplarında yer alan analojilerin ağırlıklı olarak "kişisel analoji" türünde olduğu ve sınıf seviyesi arttıkça analoji kullanımının fazlalaştı̆̆ı tespit edilmiştir. Ayrıca analojilerin öğrenme alanlarına homojen olarak dağılmadığı, nicelik ve nitelik açısından yeterli düzeyde olmadığı sonucuna ulaşılmıştır. Araştırma sonucunda Sosyal Bilgiler öğretimi kapsamında analojilerle ilgili farkındalığın artırılması ve analoji kullanımının teşvik edilmesi, mevcut analojilerin ise görsel ve sınırlı yönleri ile birlikte verilerek zenginleştirilmesi gibi önerilerde bulunulmuştur.

Anahtar sözcükler: analoji, sosyal bilgiler öğretimi, sosyal bilgiler ders kitapları

\section{Atıf:}

Şeyihoğlu, A., Özgürbüz, İ.E. ve Torun, E. (2022). İlköğretim 4-5-6 ve 7. sinıf sosyal bilgiler ders kitaplarında yer alan analojilerin incelenmesi. Pamukkale Üniversitesi Eğitim Fakültesi Dergisi, 55, 347-375.doi: 10.9779.pauefd.1014279

\footnotetext{
* Prof. Dr., Trabzon Üniversitesi, Orcid: 0000-0001-8143-3753, asegulseyihoglu@gmail.com

** Doktora Öğrencisi, Atatürk Üniversitesi, Orcid: 0000-0002-5849-0511, ozgurbuze@gmail.com

*** Arş. Gör., Trabzon Üniversitesi, Orcid: 0000-0003-3013-3691, eliftorun0325@gmail.com
} 


\section{Giriş}

Bireyin bilişsel yapısının temel kökenini oluşturan kavramlar, etkili ve kalıcı bir öğrenmenin gerçekleşmesinde önemli rol oynamaktadır (Malatyalı ve Yılmaz, 2010). Özellikle ilk ve ortaöğretim döneminde öğrenilen kavramlar, yaşam boyu yeni öğrenmelerin ilk adımıdır (Ülgen, 2001). Sosyal Bilgiler'de de kavramların doğru, anlamlı ve kalıcı öğrenilmesi önem arz etmektedir. $\mathrm{Bu}$ bağlamda yeni bilgilerin ön bilgilerle uyumlu hale getirilerek anlamlı öğrenmenin sağlanması; eğitimin niteliğini artırmak, bilgiyi somutlaştırmak, öğrenmeyi etkileyen en önemli faktörlerden biri olan kavram yanılgılarını önlemek ve kavramların doğru öğrenilmesini sağlamak açısından önem taşımaktadır. Nitekim Şimşek (2006), yaptığ1 çalışmada öğrenme etkinliklerinin bilinen ve tanıdık unsurlar üzerine gerçekleştirilmesinin bilginin anlamlı olarak algılanmasına katkı sağladığına dikkat çekmiştir. Ayrıca Köymen (2000), soyut bilgilerin aktarımında önceden bilinen unsurlardan yola çıkmanın öğrenci motivasyonunu artırdığını ve öğrencide merak duygusu oluşturduğunu ifade etmiştir. Somut kavramlar zihinde daha kolay canlandırıldığından öğrenenler somut kavramları soyut kavramlara göre daha kolay ve çabuk anlamlandırmaktadırlar. Gürkan ve Doğanay (2016) soyut kavramların soyut işlemler döneminde olmayan öğrencilere aktarımında somut unsurlardan yola çıkılması gerektiğini vurgulamaktadır. Bu noktadan hareketle Sosyal Bilgiler öğretiminde soyut kavramların somutlaştırılmasında kullanılan en önemli tekniklerden biri olan analojilerden (Atav, Erdem, Y1lmaz ve Gücüm, 2004; Bayazit, 2011; Curtis ve Reigeluth, 1984; Demir, Önen ve Şahin, 2011; Ekici, Ekici ve Aydın, 2007) yararlanılabileceği ifade edilebilir. Çünkü analojiler bilimsel kavramların öğretilmesi, geliştirilmesi ve zihinde canlandırılmasını kolaylaştıran yenilikçi bir öğretim tekniğidir (Demirci-Güler, 2007). Ayrıca analojiler bilinen kavramlardan ve kavrama ait özelliklerden yola çıkarak bilinmeyen kavrama dair çıkarımda bulunmayı sağlar (Duman, Özgürbüz ve Şeyihoğlu, 2020). Öğretim faaliyetleri sırasında özellikle gözle görülmeyen olay ve olguların öğrencilere aktarıldığı kısımlarda çeşitli zorluklar yaşanabilmektedir. Üstelik bu süreç tekdüze bir anlatımla yürütüldüğünde, öğrencinin dersten uzaklaşması kaçınılmazdır. Bu noktada analoji, öğrencinin bilişsel yapısında mevcut olan geçmiş öğrenmeler yardımıyla yabancı olduğu yeni kavram arasında bir bağ kurarak, bilgi aktarımını kolaylaştıran etkili bir araçtır (Tezcan ve Seyitoğlu, 2007). Başka bir ifade ile bilinen kavramdan yola çıkılarak bilinmeyen kavramın anlatılmaya çalışılır. Bu süreçte bilinen kavram "kaynak (araç)” olarak nitelendirilirken bilinmeyen kavram "hedef (konu)" olarak nitelendirilmektedir (Glynn ve Takahashi, 1998; Şaşmaz Ören, Ormancı, Babacan, Çiçek ve Koparan, 2010). Analojiler 
A, Şeyihoğlu, İ. E., Özgürbüz ve E, Torun/ Pamukkale Üniversitesi Eğitim Fakültesi Dergisi, 55, 347-375, 2022349 bilinen kavram ile bilinmeyen kavram arasında benzetmeler yoluyla ilişki kurarak soyut unsurları somutlaştırma ve anlaşılır hale getirme noktasında yarar sağlamaktadır.

Tüm bunlara ek olarak analojiler, yeni kavramları öğrenme ve sonuç çıkarma için etkili tekniklerden biri olup, problem çözme, açıklama yapma ve münazara aktiviteleri için uygun ortam oluşturma adına taşıdığı avantajlardan dolayı güçlü bir öğrenme ve öğretme ortamı sunar (Dilber, 2006). Analoji; bir kavramı tek bir disiplinden ziyade birden çok disiplinle ilişkilendirme, kavramlar arası düşünmeye imkan verme, öğrenci motivasyonunu ve güdülenme düzeyini artırma yönleri ile öğretim faaliyetleri için önem arz etmektedir (Barton ve Smith, 2000; Dikmenli, 2015; Duit, 1991; Gülcan, 2021; Harrison ve Treagust, 1993; Kaptan ve Arslan, 2002; Köseoğlu, vd., 2003; Reeves, Herrington ve Oliver, 2002). Analojiler, ilişkilendirme yoluyla büyük ve karmaşık durumdaki bilgilerin daha kısa kodlarla zihne yerleşmesini ve anlamlandırılmasını sağlayarak hafızadaki yükü azaltır ve bilinen ile bilinmeyen bilgi arasında kurulan bağlantı, bilginin farklı alanlara uyarlanmasını beraberinde getirir (Bayazit, 2011). Alan yazın incelendiğinde Çıray (2010) tarafindan yapılan çalışmada analoji tabanlı öğretimle öğrencilerin akademik başarılarında ve öğrenme düzeylerinde artış sağlandığı tespit edilmiştir. Ayrıca Gürkan ve Doğanay (2016) tarafindan yapılan çalışmada analojilerin; kavram özelliklerini tespit ederek kavramsal anlamaya katkı sağladığı ve bu şekilde önceki bilgilerin yeni öğrenilen bilgilerle zihinde anlamlı bütün oluşturduğu ifade edilmiştir. Eğitsel anlamda birçok avantajı bünyesinde barındıran analojiler; ilgi çekicilik, motivasyon ve görsellik sağlama (Harman ve Çökelez, 2017), soyut ve karmaşık durumları somutlaştırarak öğrenmeyi kolaylaştırma (Akkuzu ve Akcay, 2011; Heywood, 2002) noktasında oldukça işlevseldir. Ayrıca analojiler; bilgilerin daha kısa kodlarla uzun süreli belleğe aktarılmasını sağlayarak zihinsel yükü azaltan, hatırlamayı kolaylaştıran, bilginin farklı alanlarda kullanımına imkan veren (Bayazit, 2011; Şeyihoğlu ve Özgürbüz, 2015) kısacası niteliğine bağlı olarak öğrenmeyi daha güçlü hale getiren önemli araçlardandır (Duman vd., 2020).

Analojilerin literatürde farklı sınıflamalarına rastlanmaktadır. Genel olarak analojiler basit, zenginleştirilmiş, genişletilmiş ve kişisel analojiler olmak üzere dört başlık altında ele alınabilir. Basit analojiler direkt olarak bir şeyin diğer bir şeye benzetilmesidir (Şahin, 2010). Bu analoji türüne; Takım Yıldızlarından Büyükayının eğik duran bir cezveye (SB-4 s.64), topacın armuda (SB-4 s.47), horonun dalgalı bir denize (SB-5 s.46), farklı özellikteki bireylerin bir araya gelişini kilimin motiflerine (SB-6 s.32), atmosferin cam seralara (SB-7 s.215) benzetilmesi örnek verilebilir. Zenginleştirilmiş analojiler hedef ve kaynak arasındaki 
350A, Şeyihoğlu, İ. E., Özgürbüz ve E, Torun/ Pamukkale Üniversitesi Eğitim Fakültesi Dergisi, 55, 347-375, 2022 ilişkinin açıklandığı ya da hedef ve kaynak arasındaki sınırlılık veya benzemeyen yönlerin verildiği analoji türüdür. "Ülkemiz bir çiçek bahçesine benzetebilir miyiz? Bahçeyi toplumu oluşturan farklılıklar bütünü olarak düşünürsek neler söyleyebiliriz?” (SB-6 s.27) ifadesi zenginleştirilmiş analoji türüne örnek oluşturur. Genişletilmiş analojilerde ya tek bir araç birden fazla konuyu öğretmek için kullanılır, ya da farklı araçlar tek bir konuyu öğretmek için kullanılır (Curtis ve Reigeluth, 1984). "Kilimlerdeki desenlere tek tek baktığımızda bir anlam ifade etmezler. Desenler bir araya gelince zenginliğe dönüşür. Renkler desenleri, desenler motifleri, motifler de kilimi oluştururken farklılıklar bir sanata dönüşmüştür" (SB-6 s.32) cümlesi genişletilmiş analoji türüne örnektir. Kişisel analojiler ise soyut kavramları öğrencinin kendi dünya görüşü ile ilişkilendirerek öğrenmelerine yardım eder (Duman, 2016). Kişisel analojilerde öğrencinin kendini öğretilmek istenen hedef nesne, kişi ya da kavramların yerine koyarak, zihinsel veya fiziksel rol oluşturduğu analoji türüdür (Thiele ve Treagust, 1991). “Türkiye'yi ziyaret eden bir turist olsaydınız ülkenize götüreceğiniz hediyelik eşyalar neler olurdu?” (SB-4 s.190) sorusu kişisel analoji türüne bir örnektir. Şekil 1'de analoji türleri şematik olarak verilmiştir.

Eğitsel süreçlerde analoji tekniğinden yararlanılırken dikkate alınması gereken iki önemli değişkenden biri öğretmen özellikleri, diğeri ise ders kitaplarıdır (Hıdır ve Didiş Körhasan, 2018). Öğretmenlerin bireysel özellikleri ve donanımları birbirinden farklı olduğu için derslerinde analojileri kullanma durumları da değişkenlik göstermektedir. Oysa ders kitapları tüm öğretmen ve öğrencilerin kolayca ulaşabileceği, duruma göre de değişmeyen ana kaynaklardır. Öğretmenin birçok etkinliği tasarlamasına fırsat sunan ve rehber olan kitapların sınıf içindeki yerinin önemli olduğu halen kabul edilen bir gerçektir (Ceyhan ve Yiğit, 2005; Çalışkan, 2006; Çeken, 2011). Ayrıca özellikle bilişsel ve duyuşsal gelişimin şekillendiği ilköğretim döneminde ders kitaplarının önemi daha da artmaktadır. Kazandırılması hedeflenen demokratik, çağdaş, özgür, bilimsel düşünme becerileri gelişmiş, topluma karşı sorumluluklarını bilen ve yerine getiren nesillerin yetişmesi adına ders kitaplarının önemli bir rolü vardır (Kolaç, 2003). Bununla birlikte öğretim programlarının uygulanmasındaki en önemli materyallerden biri olan ders kitaplarının, belli başlı niteliklere sahip olması beklenmektedir. Yılmaz ve Çeltikçi (2013) ders kitaplarının öğretime yardımcı, destekleyici olmasının yanı sıra öğrencilerin bilgileri zihinlerinde resmetmeyi kolaylaştıran, görsel unsurlara sahip olması gerektiğini vurgular. Ayrıca ders kitapları; öğrencinin zihnindeki bilgilerin yapılandırılmasına olanak sağlayan ve "yakından uzağa, basitten 
A, Şeyihoğlu, İ. E., Özgürbüz ve E, Torun/ Pamukkale Üniversitesi Eğitim Fakültesi Dergisi, 55, 347-375, 2022351

karmaşığa, kolaydan zora ve somuttan soyuta" giden bir yöntemin izlendiği (MEB, 2006), soyut unsurların somutlaştırılarak açıklandığı kaynaklar olmalıdır (Senemoğlu, 2011). Ders kitaplarında söz konusu bu işlevleri yerine getirmeyi kolaylaştıracak, aynı zamanda da anlamlı öğrenmelerin gerçekleşmesini sağlayacak en önemli tekniklerden biri de analojidir.

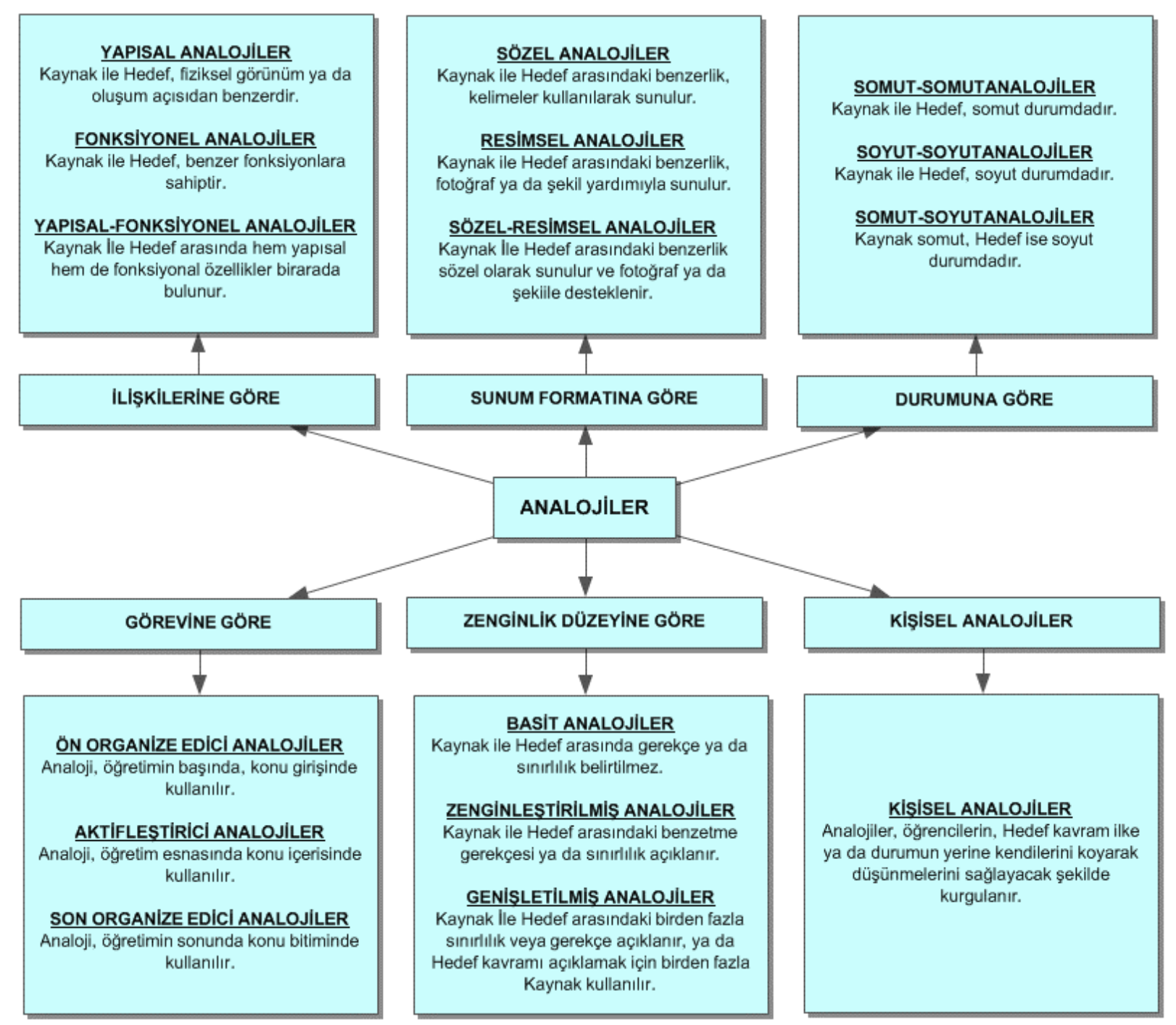

Şekil 1. Analoji Çeşitleri (Şeyihoğlu ve Özgürbüz, 2015)

Literatür incelendiğinde ders kitaplarının farklı amaçlarla değişik açılardan çok kez ele alındığı görülmektedir. Sosyal Bilgiler özelinde, ders kitapları çeşitli becerilerin (Aydemir, 2017; Karasu Avcı ve Faiz, 2018), kavramların (Akman ve Bastık, 2016; Baş, 2020; Kaçar ve Bulut, 2020) ve konuların (Gedik Demirkaya, 2008) nasıl ele alındığını tespit etmek için incelenmiş; bunun yanı sıra çeşitli sınıflama, içerik çözümlemesi (Demir ve 
352A, Şeyihoğlu, İ. E., Özgürbüz ve E, Torun/ Pamukkale Üniversitesi Eğitim Fakültesi Dergisi, 55, 347-375, 2022

Atasoy, 2018; Kaymakcı, 2013) ve program ile uyumluluk (Gülersoy, 2012) açısından değerlendirilmiştir. Yapılan literatür taramasında ders kitaplarında analojilerin incelendiği birçok çalışma bulunmasına rağmen Sosyal Bilgiler ders kitaplarının analojiler açısından ele alındığı bir çalışmaya rastlanmamıştır. Bu bağlamda ders kitaplarında analojilerin ele alındığı çalışmaların çoğunlukla Kimya (Kobak, 2013; Orgill ve Bodner 2006; Thiele ve Treagust 1994; Tufan 2019), Fen Bilgisi (Demirci-Güler ve Yağbasan, 2008; Glynn ve Takahashi 1998; Hıdır ve Didiş Körhasan, 2018; Öztürk ve Aydın 2013), Fizik (Azizoğlu, Çamurcu ve Kırtak-Ad, 2014; Kırtak-Ad ve Tüfekçi, 2021), Biyoloji (Adnan, 2015; Gülcan, 2021) Matematik (Karadeniz, 2017), Bilgisayar, (Schreglmann, 2019), Coğrafya (Şeyihoğlu ve Özgürbüz, 2015) alanlarında yapıldığı tespit edilmiştir. Sosyal Bilgiler özelinde analojilerin ele alındığı bir durum çalışması yer almaktadır (Gürkan ve Doğanay, 2016). Genel olarak literatüre bakıldığında mevcut çalışmaların yoğunlukla fen bilimleri alanında yürütülen çalışmalar olduğu belirlenmiştir. Ancak bu çalışmanın odak noktasını oluşturan 47 sınıf kapsamında Sosyal Bilgiler ders kitaplarında yer alan analojilerin değerlendirildiği çalışmaya rastlanmamıştır. Geniş tabanlı bir programa sahip olan Sosyal Bilgiler aynı zamanda mihver derslerdendir. Başka bir ifade ile birçok branşın bilimsel temellerinin yapılandırıldığ 1 temel derslerden biridir. Sosyal bilgiler öğretimi içerisinde somut bilgiler, kavramlar olduğu kadar soyut olan bilgi ve kavramlar da vardır. Çocukların bu soyut bilgileri eksiksiz ve doğru yapılandırmaları zor olabilmektedir. Bu sebeple Sosyal Bilgiler dersinde analoji kullanımı; kavram yanılgılarının tespiti, giderilmesi, konunun öğretim ilkelerine uygun şekilde basitleştirilmesi, somutlaştırılması ve yaşamdan kaynaklarla ilişkilendirilmesi gibi sebeplerle önemli bir yere sahiptir. Ayrıca öğretmenlerin en çok yararlandığ alınmasının önemli olabileceği düşünülmüştür. Her öğretmenin analoji oluşturma ve örnek sunma yeterliliğinin aynı olması beklenmemektedir. Bu durum ders kitaplarında kullanılan analojilerin niceliğini ve niteliğinin artırılması adına çalışmaları daha önemli hale getirmektedir. Analoji tekniğinin kullanımının sağladığı yararlar göz önünde bulundurularak Sosyal Bilgiler ders kitaplarında analoji tekniğinin kullanılma durumunun belirlenmesinin alana yönelik tespitte bulunma ve öneri getirmenin yararlı olacağı düşünülmektedir. $\mathrm{Bu}$ sebeple araştırmanın problem cümlesi; "4-7. sınıf Sosyal Bilgiler ders kitaplarında yer alan analojilerin kullanılma durumu nedir?” şeklindedir. Bu doğrultuda problem cümlesi ile ilintili olarak aşağıdaki alt problem cümleleri oluşturulmuştur. 
A, Şeyihoğlu, İ. E., Özgürbüz ve E, Torun/ Pamukkale Üniversitesi Eğitim Fakültesi Dergisi, 55, 347-375, 2022353

- 4-7. sinıf Sosyal Bilgiler ders kitaplarında analoji kullanımı ve bunların analojik siniflaması nasıldır?

- 4-7. sınıf Sosyal Bilgiler ders kitaplarında ders kitaplarında kullanılan analoji türlerinin öğrenme alanlarına göre dağılımı ve öğrenme alanlarına göre karşılaştırması nasıldır?

\section{Yöntem}

Bu çalışmada nitel yaklaşım benimsenerek veriler doküman analizi tekniği ile incelenmiştir. Doküman analizi, ilgili belgelerin belirli sisteme göre kodlayıp inceleme işlemidir (Çepni, 2014). Doküman analizi tekniği alanda mevcut kaynakların incelenerek genel eğilim hakkında çıkarım yapmaya olanak vermektedir. Mevcut kaynaklardaki genel eğilimin sunulması alanda eksiklik ve ihtiyacın ortaya çıkartılması, alternatif ve farklı düşüncelerin sunulması ve entegre edilmesine olanak sağlaması adına firsat sunabilir (Çepni, 2014). Dokümanlar, nitel yürütülen çalışmalarda ihtiyaç olan veriyi görüşme, gözlem ya da diğer tekniklere ihtiyaç olmadan zaman ve maliyetten tasarruf sağlayarak çalışmayı sağlar (Yıldırım ve Şimşek, 2016). Çalışmada Sosyal Bilgiler ders kitaplarında analojilerin yer alma durumu ele alındığı için bu desen tercih edilmiştir. Çalışmanın verileri doküman analizi tekniğiyle elde edilmiştir. Doküman analizi tekniği araştırma konusu ile ilgili belgelerin belirli sisteme göre kodlayıp inceleme işlemidir (Çepni, 2014). Doküman analizi tekniği alanda mevcut kaynakların incelenerek genel eğilim hakkında çıkarım yapmaya olanak vermektedir. Mevcut kaynaklardaki genel eğilimin sunulması alanda eksiklik ve ihtiyacın ortaya çıkartılması, alternatif ve farklı düşüncelerin sunulması ve entegre edilmesine olanak sağlaması adına fırsat sunabilir (Çepni, 2014). Dokümanlar, nitel yürütülen çalışmalarda ihtiyaç olan veriyi görüşme, gözlem ya da diğer tekniklere ihtiyaç olmadan zaman ve maliyetten tasarruf sağlayarak çalışmayı sağlayan bir tekniktir (Yıldırım ve Şimşek, 2016). Çalışmanın veri kaynağını meydana getiren dokümanlar, 2020-2021 eğitim öğretim döneminde 4-7. (4.5.6.-7.) sınıfta kullanılan Sosyal Bilgiler ders kitaplarıdır.

\section{İncelenen Dokümanlar}

Araştırmada 4., 5., 6. ve 7. sınıf olmak üzere dört farklı seviyedeki Sosyal Bilgiler ders kitabı incelenmiştir. 4. ve 5. sınıf ders kitapları özel yayınevleri tarafından basılmış ve 208'er sayfa iken 6. sinıf ders kitabı 276, 7. sınıf ders kitabı 240 sayfa olup MEB tarafindan basılmıştır. 
354A, Şeyihoğlu, İ. E., Özgürbüz ve E, Torun/ Pamukkale Üniversitesi Eğitim Fakültesi Dergisi, 55, 347-375, 2022

Tablo 1. Analiz Edilen Sosyal Bilgiler Ders Kitaplart

\begin{tabular}{cccccc}
\hline Ders Kitabı No & Sınıf & Yayınevi & Yazarlar ve Basım Yılı & $\begin{array}{c}\text { Cilt } \\
\text { Sayısı }\end{array}$ & $\begin{array}{c}\text { Sayfa } \\
\text { Sayısı }\end{array}$ \\
\hline DK1 & 4 & Tuna & Tüysüz, 2019 & 1 & 208 \\
\hline DK2 & 5 & Anadol & Şahin, 2019 & 1 & 208 \\
\hline DK3 & 6 & MEB & Yıldırım, Kaplan, Kuru ve & 1 & 276 \\
& & & Yılmaz, 2019 & \\
\hline DK4 & 7 & MEB & Açıl, Güvenç, Hayta ve & 1 & 240 \\
& & & Kılıç, 2019 & \\
\hline
\end{tabular}

\section{Veri Toplama Süreci}

Çalışmanın veri toplama süreci etik kurul onayı alındıktan sonra başlatılmıştır. Bu bağlamda çalışmanın etik kurul incelemesi Trabzon Üniversitesi Sosyal ve Beşeri Bilimler Bilimsel Araştırma ve Yayın Etik Kurulu tarafından yapılmış ve 13.10.2020 tarih "81614018-000E.405" sayılı karar ile çalışmanın yapılması etik olarak uygun bulunmuştur. Etik kurul izninin alınmasının ardından ders kitaplarının inceleme süreci başlatılmıştır.

\section{Veri Analizi}

Çalışmada Sosyal Bilgiler ders kitaplarındaki analojileri tespit etmek için içerik analizi kullanılırken, analojileri türlerine ve öğrenme alanlarına göre sınıflandırmak için betimsel analiz kullanılmıştır. Betimsel analiz bir konu ya da durumun olduğu gibi resmedilip tanımlanması olarak ifade edilebilir (Ekiz, 2017). Betimsel analiz yapılırken kodlar önceden mevcuttur ve araştırmanın kavramsal yapısının bilindiği çalışmalarda tercih edilen bir analiz türüdür (Çepni, 2014).

Çalışmada farklı sınıf seviyelerinde kullanılan ders kitaplarında tespit edilen analojiler; nicelik ve nitelik açısından incelenerek analojik sınıflandırmaya dahil edilmiş ve her bir araştırmacı tarafından ayrı ayrı kodlanmıştır. İncelenen ders kitaplarındaki analojilerin gruplandırılmasında, Curtis ve Reigeluth (1984); Thiele ve Treagust (1991) ve Şahin (2010)'in çalışmalarında yer alan analoji kategorileri esas alınmıştır. MEB ve özel yayın evleri tarafından basılan dört ders kitabının doküman olarak incelendiği çalışmada ilk olarak ders kitapları araştırmacılar tarafından bağımsız olarak okunmuş ve tespit edilen analojiler araştırmacılar tarafından yine bağımsız olarak kodlanıp sınıflandırılmıştır. Sonrasında araştırmacılar bir araya gelerek bağımsız olarak kodladıkları analojileri ve sınıflandırmaları karşılaştırmış ve görüş birliğini sağlayan kodlar tablolaştırılmıştır. Örneğin 
A, Şeyihoğlu, İ. E., Özgürbüz ve E, Torun/ Pamukkale Üniversitesi Eğitim Fakültesi Dergisi, 55, 347-375, 2022355

5. sınıf Sosyal Bilgiler ders kitabı sayfa 148'deki analojiler iki araştırmacı tarafından ayrı analojiler olarak değerlendirilirken bir araştırmacı tarafından bir analoji olarak kabul edilmiştir. Bu durumda söz konusu analojiler için fikir alışverişinde bulunularak her bir ifadenin farklı analoji olarak kabul edilmesi gerektiği kararı alınmıştır. Yaklaşık 7 ay sonra araştırmacılar tekrar bir araya gelerek önceden belirledikleri analojileri tekrar kodlamıştır. Araştırmacılar önce ve sonra oluşturdukları kodları karşılaştırmış ve böylelikle çalışmanın hem iç güvenirliği yani tutarlılığı hem de zamana karşı dış geçerliği yani tekrar edilebilirliği sağlanmıştır (Yıldırım ve Şimşek, 2016). Şekil 2'de analojilerin analizine ve kodlanmasına ilişkin bir örneğe yer verilmiştir

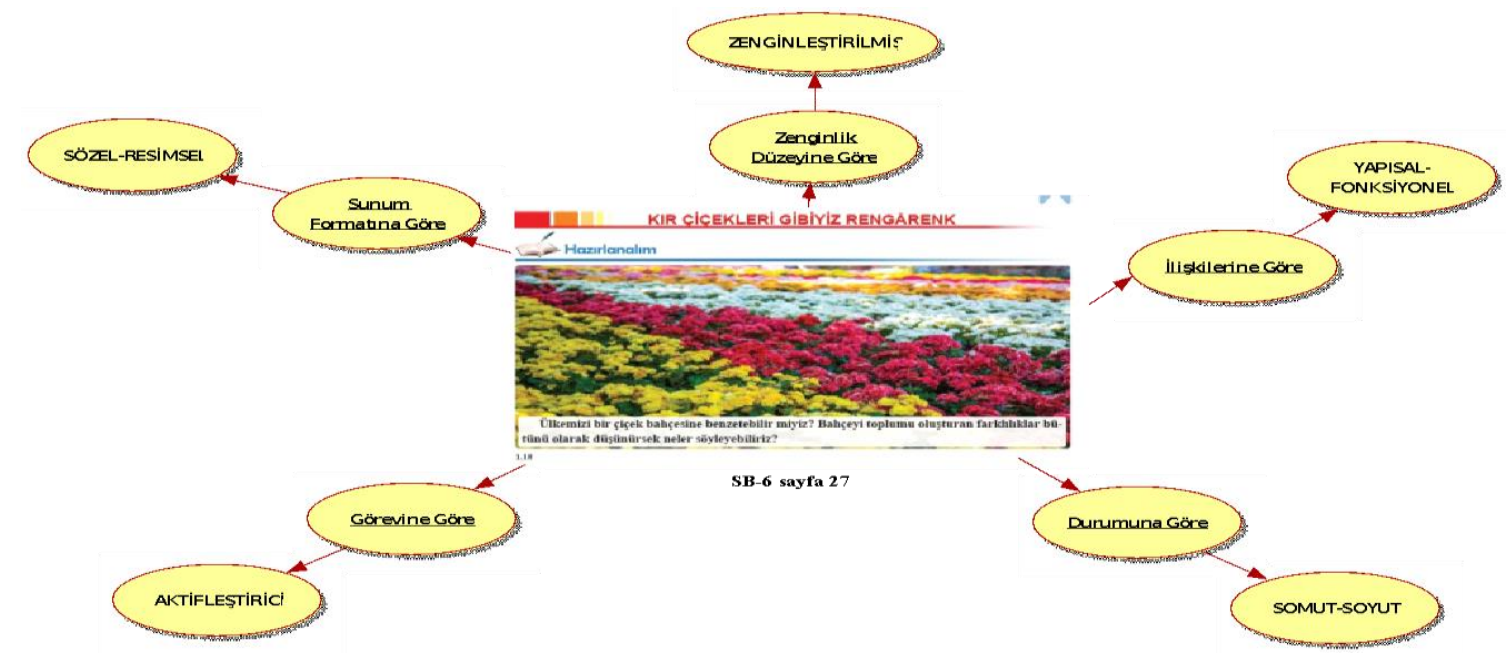

Şekil 2. 6. sınıf Sosyal Bilgiler ders kitabı analoji analizi örnĕgi

Araştırmada görüş birliği sağlanan veriler Çepni’nin (2014) de belirttiği gibi sayısallaştırılmış ve tablolar halinde sunulmuştur. Bu bağlamda farklı sınıf seviyelerindeki Sosyal Bilgiler ders kitaplarında yer alan analojilerin kullanılma durumu, öğrenme alanlarına göre dağılımı ve türlerine ait bulgular tablolaştırılmıştır. Her bir tabloyu açıklayan bilgilere ilgili tablonun altında yer verilmiştir. Tablo ve metin içerisinde sınıf seviyesi ve sayfa numarasını belirten kodlar kullanılarak verilerin ders kitabından teyit edilebilirliği sağlanmıştır. Örneğin SB5-78 kodu; Sosyal Bilgiler 5. sınıf ders kitabının 78. sayfasını belirtmektedir. Ayrıca bazı tablolarda ilgili sınıf düzeyi için sütun oluşturulmuş ve sayfa numarasına yer verilerek analojinin ilgili ders kitabından kontrolünün mümkünlüğü sağlanmıştır. Örneğin Tablo 4'te 4.sınıf düzeyinde Bilim ve Toplum öğrenme alanında iki analoji bulunmaktadır. Bu iki analojinin tasnifi yapılırken, bulunduğu sayfa numarası ve satır sayısı ile sunulmuştur. Ayrıca toplam ifadesiyle ilgili sınıf düzeyinin öğrenme alanında kullanılan analojilerin frekans bilgisine yer verilmiştir. Aynı sayfada birden çok analojinin 
356A, Şeyihoğlu, İ. E., Özgürbüz ve E, Torun/ Pamukkale Üniversitesi Eğitim Fakültesi Dergisi, 55, 347-375, 2022 bulunması durumunda ilgili sayfa numarasına her biri bir analojiyi temsil eden "a-b-c" gibi harfler verilmiştir. Örneğin SB7-177a kodu 7.sınıf Sosyal Bilgiler ders kitabı sayfa 177 de bulunan bir analojiyi temsil ederken, SB6-148abcd kodu 6.sınıf Sosyal Bilgiler ders kitab1 sayfa 148 'de bulunan aynı türdeki dört analojiyi temsil etmektedir.

\section{Bulgular}

Bu bölümde araştırmanın problem cümlesine uygun olarak 4-7. sınıf Sosyal Bilgiler ders kitaplarında yer alan analojilerin kullanılma durumu ve bunların analojik sınıflamaya, sınıf düzeylerine ve öğrenme alanlarına göre dağılımı tablolaştırılarak ifade edilmeye çalışılmıştır.

\section{Birinci alt probleme dair bulgular}

Araştırmanın birinci alt problemi kapsamında 4., 5., 6. ve 7. sınıf Sosyal Bilgiler ders kitaplarında kullanılan analojilerin, analoji türleri ile sınıf seviyelerine göre dağılımı incelenmiş ve elde edilen veriler Tablo 2 ve Tablo 3 'te sunulmuştur.

Tablo 2. Sosyal Bilgiler Ders Kitaplarındaki Analojilerin Kullanılma Durumu ve Analojik Sinıflamaya Göre Dă̆ılımı

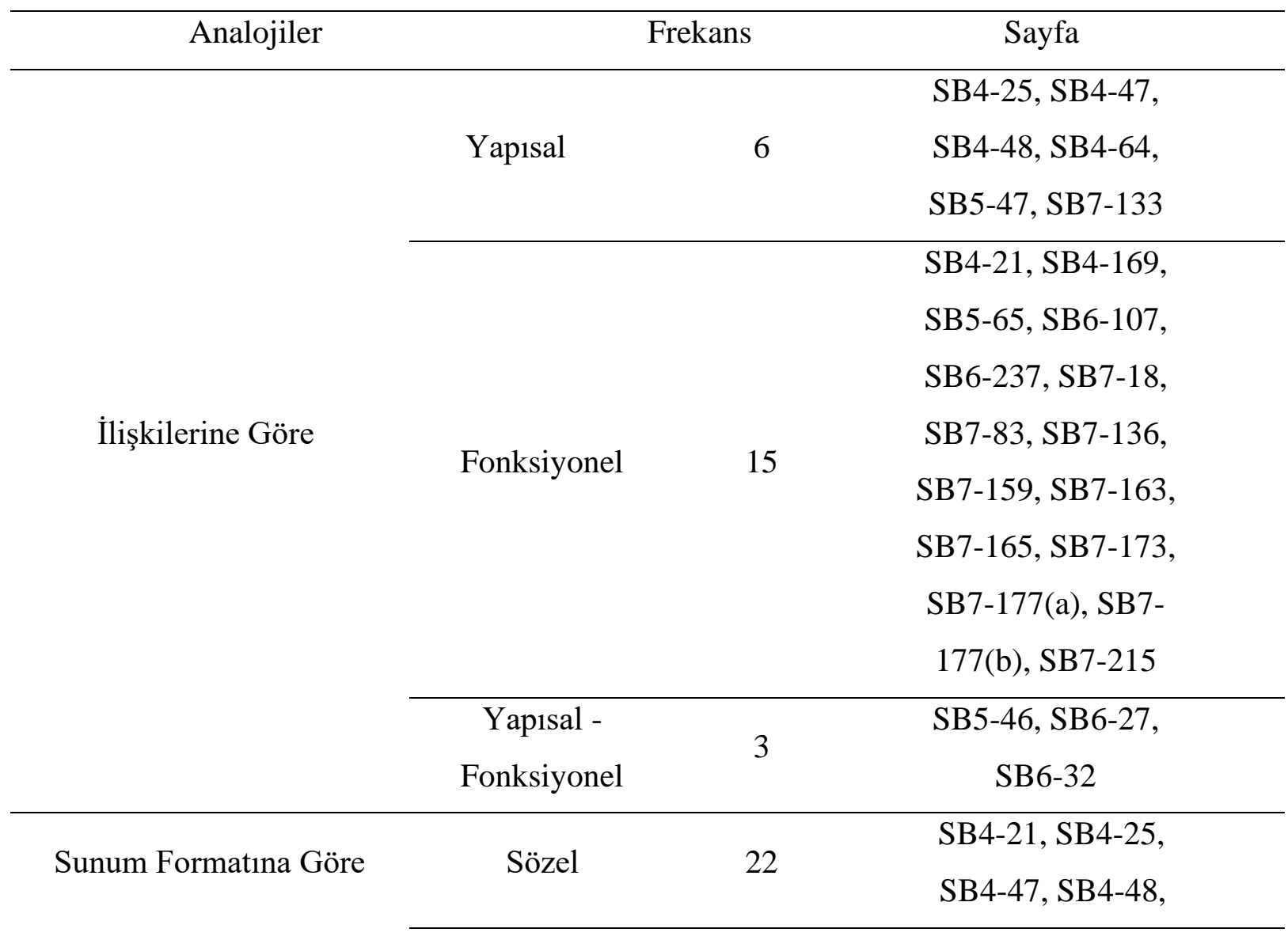


SB4-64, SB4-169,

SB5-46, SB5-47,

SB5-65, SB6-27,

SB6-107, SB6-

237, SB7-18,

SB7-83, SB7-136,

SB7-159, SB7-

163, SB7-165,

SB7-173, SB7-

177(a), SB7-

177(b), SB7-215

\begin{tabular}{ccc}
\hline Resimsel & - & \\
\hline Sözel - & 2 & SB6-32, SB7-133 \\
Resimsel & &
\end{tabular}

SB4-25, SB4-47,

SB4-64, SB5-46,

SB5-47, SB5-65,

SB6-107, SB6-237,

Somut - Somut

16

SB7-18, SB7-83,

SB7-133, SB7-159,

Durumuna Göre

SB7-163, SB7-165,

SB7-173, SB7-

177(b)

\begin{tabular}{ccc}
\hline Soyut - Soyut & - & \\
\hline & SB4-21, SB4-48, \\
& SB4-169, SB6-27, \\
Somut - Soyut & 8 & SB6-32, SB7-136, \\
& SB7-177(a), SB7- \\
& 215
\end{tabular}

SB4-25, SB4-47,

Görevine Göre

Ön Organize

Edici
9

SB6-27, SB6-107,

SB6-237, SB7-133,

SB7-159, SB7-165, 
SB4-21, SB4-64,

SB4-169, SB5-46,

SB5-47, SB5-65,

Aktifleştirici

13

SB6-32, SB7-18,

SB7-83, SB7-136,

SB7-163, SB7-

177(a), SB7-177(b)

Son Organize

Edici

2

SB4-48, SB7-173

SB4-47, SB4-48,

SB4-64, SB4-169,

SB5-47, SB5-65,

Basit $\quad 13 \quad$ SB6-107, SB7-18,

SB7-83, SB7-136,

SB7-159, SB7-173,

SB7-177(a)

Zenginlik Düzeyine Göre

SB4-25, SB6-27,

Zenginleştirilm

SB6-237, SB7-

iş

8 133, SB7-163,

SB7-165, SB7-

177(b), SB7-215

SB4-21, SB5-46, SB6-32

Toplam

24

SB4-190, SB5-42,148(a-

b-c-d), SB6-139(a-b-c-

Kişisel Analojiler

20

d),202, SB7-

$29,146,147,151,162,170$,

$181,184,212$

Genel Toplam

44 
A, Şeyihoğlu, İ. E., Özgürbüz ve E, Torun/ Pamukkale Üniversitesi Eğitim Fakültesi Dergisi, 55, 347-375, 2022359

Tablo 2'de görüldüğü gibi 4., 5., 6. ve 7. sınıf Sosyal Bilgiler ders kitaplarında; ilişkileri, sunum formatı, durumu ve görevine göre sınıflandırılabilecek türde 24 ve kişisel türde 20 olmak üzere toplamda 44 analoji tespit edilmiştir. Ders kitaplarında Sunum formatına göre resimsel ve durumuna göre soyut-soyut analoji türlerine rastlanmazken tüm ders kitaplarında en az bir analoji türüne yer verildiği tespit edilmiştir. Ders kitaplarında nadiren yer verilen analoji türü sunum formatına göre, sözel - resimsel (2), görevine göre son organize edici (2), ilişkilerine göre yapısal-fonksiyonel (3) ve zenginlik düzeyine göre genişletilmiş (3) analojidir. Ders kitaplarında ağırlıklı olarak yer verilen analoji türünün ise sunum formatına göre sözel, durumuna göre somut-somut ve kişisel analoji olduğu tespit edilmiştir.

Tablo 3. Sosyal Bilgiler Ders Kitaplarındaki Analoji Türlerinin Sinıf Seviyelerine Göre Dağılımı

\begin{tabular}{|c|c|c|c|c|c|c|}
\hline \multicolumn{2}{|c|}{ Analojiler } & 4. Sinif & 5. Sinif & 6. Sinıf & '. Sinif & Toplam \\
\hline \multirow{3}{*}{ İlişkilerine Göre } & Yapısal & 4 & 1 & - & 1 & 6 \\
\hline & Fonksiyonel & 2 & 1 & 2 & 10 & 15 \\
\hline & $\begin{array}{c}\text { Yapisal - } \\
\text { Fonksiyonel }\end{array}$ & - & 1 & 2 & - & 3 \\
\hline \multirow{3}{*}{$\begin{array}{c}\text { Sunum Formatına } \\
\text { Göre }\end{array}$} & Sözel & 6 & 3 & 3 & 10 & 22 \\
\hline & Resimsel & - & - & - & - & - \\
\hline & $\begin{array}{c}\text { Sözel - } \\
\text { Resimsel }\end{array}$ & - & - & 1 & 1 & 2 \\
\hline \multirow{3}{*}{ Durumuna Göre } & Somut - Somut & 3 & 3 & 2 & 8 & 16 \\
\hline & Soyut - Soyut & - & - & - & - & - \\
\hline & Somut - Soyut & 3 & - & 2 & 3 & 8 \\
\hline \multirow{3}{*}{ Görevine Göre } & $\begin{array}{c}\text { Ön Organize } \\
\text { Edici }\end{array}$ & 2 & - & 3 & 4 & 9 \\
\hline & Aktifleştirici & 3 & 3 & 1 & 6 & 13 \\
\hline & $\begin{array}{c}\text { Son Organize } \\
\text { Edici }\end{array}$ & 1 & - & - & 1 & 2 \\
\hline \multirow{3}{*}{$\begin{array}{l}\text { Zenginlik Düzeyine } \\
\text { Göre }\end{array}$} & Basit & 4 & 2 & 1 & 6 & 13 \\
\hline & Zenginleştirilmiş & 1 & - & 2 & 5 & 8 \\
\hline & Genişletilmiş & 1 & 1 & 1 & - & 3 \\
\hline \multicolumn{2}{|l|}{ Kişisel Analojiler } & 1 & 5 & 5 & 9 & 20 \\
\hline \multicolumn{2}{|c|}{ Toplam } & 7 & 8 & 9 & 20 & 44 \\
\hline
\end{tabular}

Tablo 3’te görüldüğü gibi 4. sınıf ders kitabında ilişkilerine göre 4 yapısal, 2 fonksiyonel analojiye yer verilirken yapısal fonksiyonel analojiye ise hiç yer verilmemiştir. 4. sınıf ders kitabında sunum formatına göre 6 sözel analojiye yer verilirken sözel resimsel 
360A, Şeyihoğlu, İ. E., Özgürbüz ve E, Torun/ Pamukkale Üniversitesi Eğitim Fakültesi Dergisi, 55, 347-375, 2022 ve resimsel analoji hiç kullanılmamıştır. 4. sınıf ders kitabında durumuna göre somut-somut 3 ve somut-soyut 3 analojiye yer verilirken soyut- soyut analoji türüne hiç yer verilmemiştir. Görevine göre 2 ön organize edici 3 aktifleştirici 1 son organize edici analojiye yer verilirken, zenginlik düzeyine göre 4 basit 1 genişletilmiş 1 zenginleştirilmiş analojiye yer verilmiştir. 4. sınıf ders kitabında 1 kişisel analojiye yer verilmiştir. 4. sınıf Sosyal Bilgiler ders kitabında toplamda 7 analoji tespit edilmiştir. Ders kitabında ağırlıklı olarak yapısal, sözel, basit analoji türüne yer verilirken yapısal fonksiyonel, resimsel, sözel-resimsel ve soyut-soyut analoji türüne hiç yer verilmemiştir.

Tablo 3'e göre 5. sınıf ders kitabında ilişkilerine göre 1 yapısal, 1 fonksiyonel, 1 yapısal fonksiyonel analoji türüne yer verilmiştir. 5. sınıf ders kitabında sunum formatına göre 3 sözel analojiye yer verilirken resimsel ve sözel resimsel analoji hiç kullanılmamıştır. Yine 5. sınıf ders kitabında durumuna göre somut-somut 3 analojiye yer verilirken, somutsoyut ve soyut- soyut analoji türüne hiç yer verilmemiştir. Görevine göre, 3 aktifleştirici analojiye yer verilirken ön organize edici ve son organize edici analoji türüne hiç yer verilmemiştir. Zenginlik düzeyine göre 2 basit analojiye yer verilirken zenginleştirilmiş ve genişletilmiş analoji türüne hiç yer verilmemiştir. 5. sınıf ders kitabında 5 kişisel analojiye yer verilmiştir. 5. sınıf Sosyal Bilgiler ders kitabında toplamda 8 analoji tespit edilmiştir. Ders kitabında ağırlıklı olarak kişisel analoji türünde 5 analojiye yer verilirken resimsel, sözel-resimsel, soyut-soyut, somut-soyut, ön organize edici, son organize edici ve zenginleştirilmiş analoji türüne hiç yer verilmemiştir.

Tablo 3 'te görüldüğü gibi 6. sınıf ders kitabında ilişskilerine göre 2 fonksiyonel ve 2 yapısal fonksiyonel analojiye yer verilirken yapısal analoji türüne hiç yer verilmemiştir. Sunum formatına göre 3 sözel, 3 sözel resimsel analojiye yer verilirken resimsel analoji hiç kullanılmamıştır. 6. sınıf ders kitabında durumuna göre 2 somut-somut analoji, 2 somutsoyut analojiye yer verilirken soyut- soyut analoji türüne hiç yer verilmemiştir. Görevine göre 3 ön organize edici ve 1 aktifleştirici analojiye yer verilirken son organize edici analoji türüne hiç yer verilmemiştir. Zenginlik düzeyine göre 1 basit, 1 genişletilmiş ve 2 zenginleştirilmiş analojiye yer verilmiştir. 6. sınıf ders kitabında 5 kişisel analojiye yer verilmiştir. 6. sınıf Sosyal Bilgiler ders kitabında toplamda 9 analoji tespit edilmiştir. Ders kitabında ağırlıklı olarak kişisel analoji türüne yer verilirken yapısal, resimsel ve soyut-soyut analoji türüne hiç yer verilmemiştir.

Tablo 3'te de görüldüğü üzere 7. sınıf ders kitabında ilişkilerine göre 1 yapısal ve 10 fonksiyonel analojiye yer verilirken yapısal fonksiyonel analoji türüne hiç yer verilmemiştir. 
A, Şeyihoğlu, İ. E., Özgürbüz ve E, Torun/ Pamukkale Üniversitesi Eğitim Fakültesi Dergisi, 55, 347-375, 2022361

Sunum formatına göre 10 sözel, 1 sözel resimsel analojiye yer verilirken resimsel analoji hiç kullanılmamıştır. 7. sınıf ders kitabında durumuna göre 8 somut-somut ve 3 somut-soyut analojiye yer verilirken soyut- soyut analoji türlerine hiç yer verilmemiştir. Görevine göre 4 ön organize edici 6 aktifleştirici ve 1 son organize edici analojiye yer verilmiştir. Zenginlik düzeyine göre 6 basit ve 5 zenginleştirilmiş analoji tespit edilirken, genişletilmiş analoji türüne hiç yer verilmemiştir. 7. sınıf Sosyal Bilgiler ders kitabında 9 kişisel analojiye yer verilmiştir. 7. sınıf Sosyal Bilgiler ders kitaplarında toplamda 20 analoji tespit edilmiştir. Ders kitabında ağırlıklı olarak fonksiyonel ve sözel analoji türüne yer verilirken yapısalfonksiyonel, resimsel, soyut-soyut ve genişletilmiş analoji türüne hiç yer verilmemiştir. 7 . sınıf Sosyal Bilgiler ders kitabının incelenen diğer ders kitapları ile kıyaslandığında analoji kullanımının daha ön planda tutulduğu tespit edilmiştir.

\section{İkinci alt probleme dair bulgular}

Araştırmanın ikinci alt probleminde 4.-7. sınıf Sosyal Bilgiler ders kitabındaki analojilerin öğrenme alanlarına göre dağılımı ve analoji türlerine göre sınıflandırılması incelenmiştir. Bu çerçevede 4.-7. sınıf Sosyal Bilgiler ders kitabında bulunan analoji türlerinin ve analojilerin öğrenme alanlarına dağılımı Tablo 4 'te sunulmuştur.

Tablo 4. Sosyal Bilgiler Ders Kitaplarındaki Analojilerin Öğrenme Alanlarına ve Analoji Türlerine Göre Sinıflandırılması

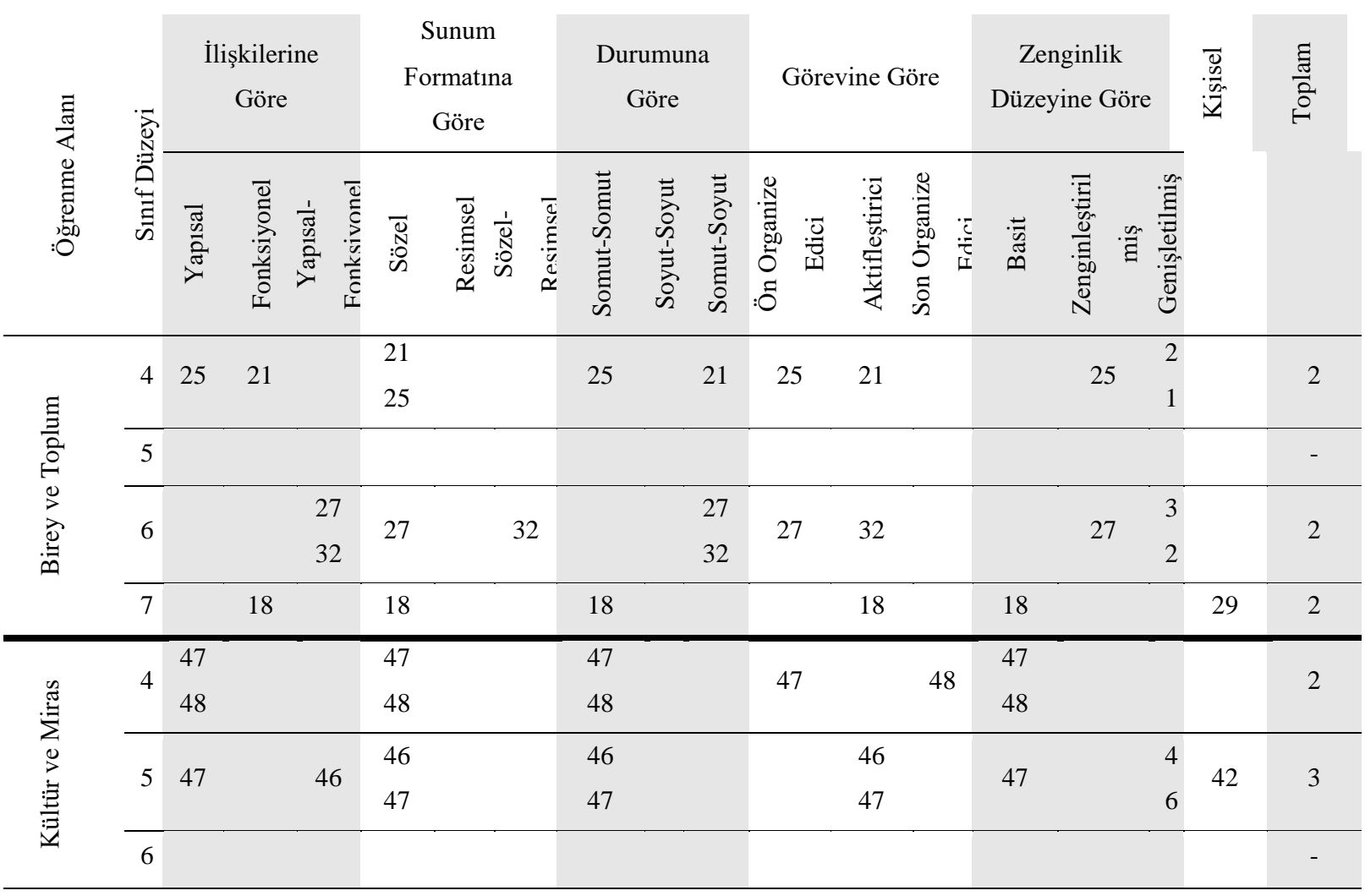


362A, Şeyihoğlu, İ. E., Özgürbüz ve E, Torun/ Pamukkale Üniversitesi Eğitim Fakültesi Dergisi, 55, 347-375, 2022

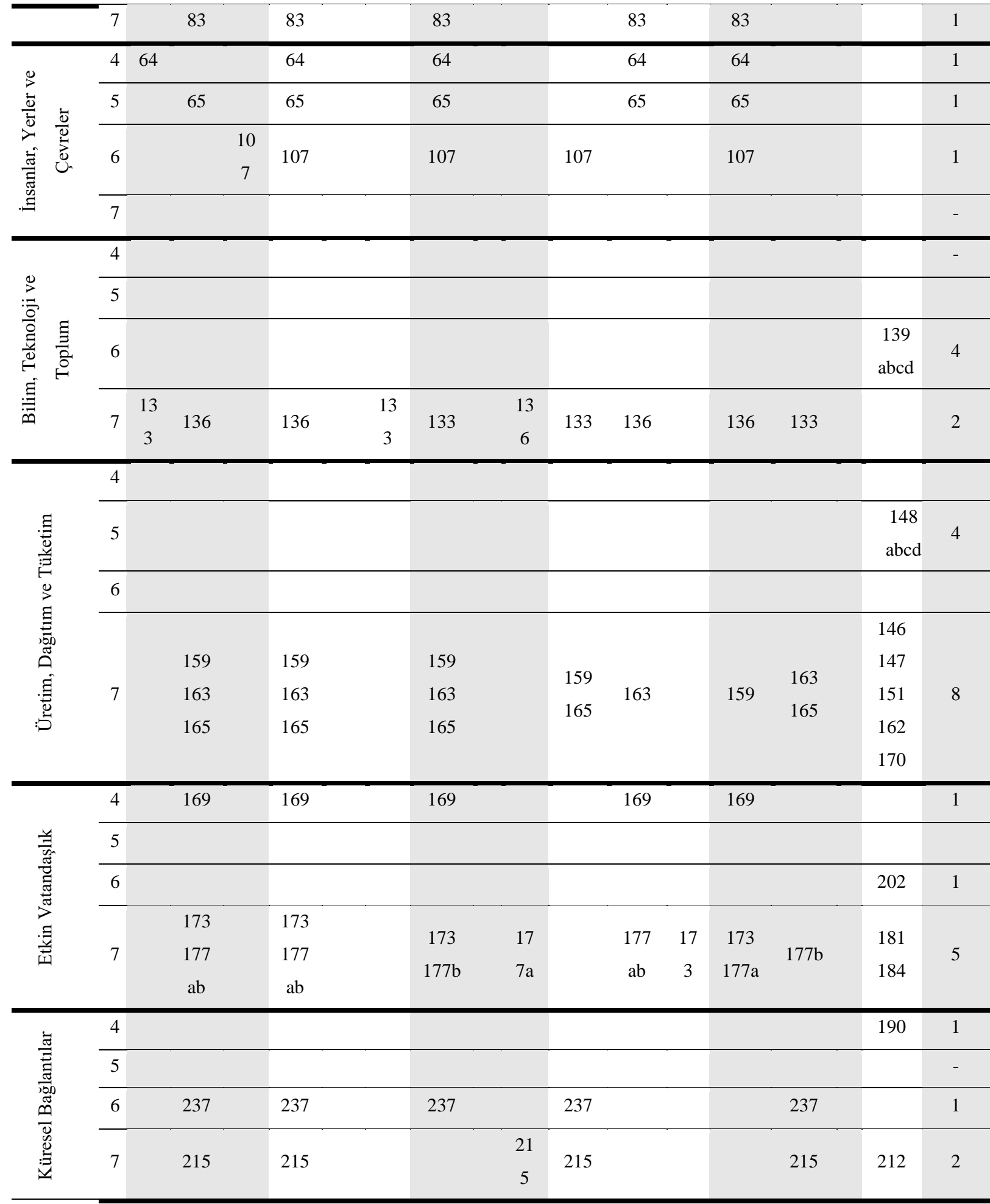

4. sınıf Sosyal Bilgiler ders kitabında tespit edilen toplam 7 analojinin öğrenme alanlarına dağılımına göre; "Birey ve Toplum” öğrenme alanında bir fonksiyonel, bir yapısal iki sözel, bir somut-somut, bir somut-soyut, bir aktifleştirici, bir ön organize edici, bir zenginleştirilmiş bir genişletilmiş olmak üzere 2 analoji kullanılmıştır. 4. sınıf Sosyal Bilgiler ders kitabının “Kültür ve Miras” öğrenme alanında iki fonksiyonel, iki sözel, iki somut-somut, bir ön organize edici, bir son organize edici iki basit olmak üzere 2 analoji 
A, Şeyihoğlu, İ. E., Özgürbüz ve E, Torun/ Pamukkale Üniversitesi Eğitim Fakültesi Dergisi, 55, 347-375, 2022363 kullanılmıştır. "İnsanlar, Yerler ve Çevreler” öğrenme alanında ise bir yapısal, bir sözel, bir somut-somut, bir aktifleştirici, bir basit olmak üzere 1 analoji kullanılmıştır. "Etkin Vatandaşlık" öğrenme alanı incelendiğinde bir fonksiyonel, bir sözel, bir somut-somut bir aktifleştirici, bir basit olmak üzere 1 analoji kullanıldığı görülmüştür. Bir diğer öğrenme alanı olan "Küresel Bağlantılar" öğrenme alanında ise bir kişisel analojiye yer verilirken, “Bilim, Teknoloji ve Toplum” ve “Üretim, Dağıtım ve Tüketim” öğrenme alanlarında analoji tespit edilememiştir (Tablo 4). Bu durumda analojiler yoğun olarak ilk iki öğrenme alanı olan "Birey ve Toplum" ve "Kültür ve Miras" öğrenme alanlarında bulunmaktadır. Buna karşılık “Bilim, Teknoloji ve Toplum” ve "Üretim, Dağıtım ve Tüketim” öğrenme alanında öğrenme alanlarında analoji bulunmamaktadır.

5. sınıf Sosyal Bilgiler ders kitabında tespit edilen toplam 8 analojinin öğrenme alanlarına dağılımına göre; "Kültür ve Miras" öğrenme alanında 1 yapısal 1 yapısalfonksiyonel, 2 sözel, 2 somut-somut, 2 aktifleştirici, 1 basit 1 genişletilmiş, 1 kişisel olmak üzere 3 analojinin kullanıldığı görülmüştür. Bir diğer öğrenme alanı olan "İnsanlar, Yerler ve Çevreler" öğrenme alanında 1 fonksiyonel, 1 sözel, 1 somut-somut, 1 aktifleştirici, 1 basit olmak üzere 1 analoji kullanılmıştır. "Üretim, Dağıtım ve Tüketim” öğrenme alanında 4, "Küresel Bağlantılar” öğrenme alanında ise 1 kişisel analojiye yer verilmiştir. Bu durumda "Üretim, Dağıtım ve Tüketim” öğrenme alanında analoji kullanımı daha ön planda tutulmuştur. Buna karşılık "Birey ve Toplum" "Bilim, Teknoloji ve Toplum" "Etkin Vatandaşlık" ve "Küresel Bağlantılar” öğrenme alanında öğrenme alanlarında analoji tespit edilememiştir.

6. sınıf Sosyal Bilgiler ders kitabında tespit edilen toplam 9 analojinin öğrenme alanlarına dağılımına göre; "Birey ve Toplum” öğrenme alanında 2 yapısal-fonksiyonel, 1 sözel, 1 sözel-resimsel, 2 somut-soyut, 1 aktifleştirici, 1 ön organize edici, 1 zenginleştirilmiş 1 genişletilmiş olmak üzere 2 analoji kullanılmıştır. "İnsanlar, Yerler ve Çevreler" öğrenme alanında yapısal-fonksiyonel, sözel, somut-somut, ön organize edici ve basit türde olmak üzere 1 analoji kullanılmıştır. Bir diğer öğrenme alanlarından olan "Bilim, Teknoloji ve Toplum" öğrenme alanında 4, "Etkin Vatandaşlık" öğrenme alanında ise 1 kişisel analojiye yer verilmiştir. Yine "Küresel Bağlantılar” öğrenme alanında fonksiyonel, sözel, somut-somut, ön organize edici ve zenginleştirilmiş türde olmak üzere 1 analoji kullanılmıştır. Bu durumda en yoğun analoji "Bilim, Teknoloji ve Toplum” öğrenme alanında bulunurken; "Kültür ve Miras" ve "Üretim, Dağıtım ve Tüketim” öğrenme alanlarında öğrenme alanında analojinin bulunmadığı tespit edilmiştir. 
364A, Şeyihoğlu, İ. E., Özgürbüz ve E, Torun/ Pamukkale Üniversitesi Eğitim Fakültesi Dergisi, 55, 347-375, 2022

7. sınıf Sosyal Bilgiler ders kitabında tespit edilen toplam 20 analojinin öğrenme alanlarına dağılımını ele aldığımızda "Birey ve Toplum” öğrenme alanında 1 fonksiyonel, 1 sözel, 1 somut-somut, 1 aktifleştirici, 1 basit ve 1 kişisel olmak üzere 2 analojinin kullanıldı̆̆1 görülmüştür. "Kültür ve Miras” öğrenme alanında fonksiyonel, sözel, somutsomut, aktifleştirici ve basit türde olmak üzere 1 analoji kullanılmıştır. Bir diğer öğrenme alanı olan "Bilim, Teknoloji ve Toplum” öğrenme alanında 1 yapısal, 1 fonksiyonel, 1 sözel, 1 sözel-resim, 1 somut-somut, 1 somut-soyut, 1 aktifleştirici, 1 ön organize edici, 1 basit ve 1 zenginleştirilmiş olmak üzere 2 analojiye yer verilmiştir. "Üretim, Dağıtım ve Tüketim” öğrenme alanında ise 3 fonksiyonel, 3 sözel, 3 somut-somut, 2 ön organize edici, 1 aktifleştirici, 1 basit, 2 zenginleştirilmiş ve 5 kişisel olmak üzere 8 analojiye yer verilmişsir. "Etkin Vatandaşlık” öğrenme alanında 3 fonksiyonel, 3 sözel, 2 somut-somut, 1 somutsoyut, 2 aktifleştirici, 1 son organize edici, 2 basit, 1 zenginleştirilmiş ve 2 kişisel olmak üzere 5 analojiye yer verildiği tespit edilmiştir. "Küresel Bağlantılar” öğrenme alanında 1 fonksiyonel, 1 sözel, 1 somut-soyut, 1 ön organize edici, 1 zenginleştirilmiş ve 1 kişisel olmak üzere 2 analojiye yer verilmiştir. Bu durumda ağırlıklı olarak analoji "Üretim, Dağıtım ve Tüketim” öğrenme alanında bulunurken; “İnsanlar, Yerler ve Çevreler” öğrenme alanında öğrenme alanında analojinin bulunmadığı tespit edilmiştir. 7. sınıf Sosyal Bilgiler ders kitabı incelenen diğer ders kitapları ile kıyaslandığında analoji kullanımının daha ön planda tutulduğu tespit edilmiştir.

Araştırmanın ikinci alt problemi kapsamında 4-7. sınıf Sosyal Bilgiler ders kitaplarındaki analojiler öğrenme alanları açısından karşılaştırılmıştır. $\mathrm{Bu}$ karşılaştırma sonucunda elde edilen bulgular şu şekildedir:

- "Birey ve Toplum” öğrenme alanında 4-7. sınıfta ikişer analoji tespit edilirken aynı öğrenme alanında 5. sınıf düzeyinde analoji tespit edilememiştir.

- "Kültür ve Miras” öğrenme alanında 4. sınıfta 2, 5.sınıfta 3, 7. sınıfta 1 analoji tespit edilirken aynı ögrenme alanında 6. sınıf ders kitabında analoji tespit edilememiştir.

- “İnsanlar, Yerler ve Çevreler” öğrenme alanında 4-5-6. sınıfta birer adet analoji tespit edilmişken, aynı öğrenme alanında 7. sınıf ders kitabında analoji tespit edilememiştir.

- "Bilim, Teknoloji ve Toplum” öğrenme alanında 6. sınıfta 4, 7. sınıfta 2 analoji tespit edilmişken, aynı öğrenme alanında 4. ve 5. sınıf düzeyinde analoji tespit edilememiştir.

- “Üretim, Dağıtım ve Tüketim” öğrenme alanında 5. sınıfta 4, 7. sınıfa 8 analoji tespit edilirken, 4. ve 6. sınıf ders kitaplarında analoji tespit edilememiştir. 
A, Şeyihoğlu, İ. E., Özgürbüz ve E, Torun/ Pamukkale Üniversitesi Eğitim Fakültesi Dergisi, 55, 347-375, 2022365

- "Etkin Vatandaşlık" öğrenme alanında 4. ve 6. sınıfta bir, 7. sınıfta beş analoji tespit edilirken, aynı öğrenme alanında 5. sınıf ders kitabında analoji tespit edilememiştir.

- “Küresel Bağlantılar'” öğrenme alanında 4. ve 6. sınıf ders kitabında birer, 7. sınıfta iki analoji tespit edilirken, aynı öğrenme alanında 5. sınıf ders kitabında analoji tespit edilememiştir.

\section{Tartışma ve Sonuç}

Araştırma sonucunda 4. sınıf Sosyal Bilgiler ders kitabında 7, 5. sınıfta 8, 6. sinıfta 9 ve 7. sınıfta 20 olmak üzere 7 öğrenme alanında toplam 44 adet analoji kullanıldığ görülmüştür (Tablo 3). Genel olarak Sosyal Bilgiler ders kitaplarında analojilere nadiren yer verildiği söylenebilir. $\mathrm{Bu}$ sonuca ek olarak, kullanılan analojilerde genel olarak sinırlılıkların belirtilmediği görülmüştür. Başka bir ifade ile analojilerin zenginlik düzeyleri zayıf bulunmuştur. $\mathrm{Bu}$ sonuç literatürde yapılmış bazı çalışmalarla örtüşmektedir: Kaya (2010), yapmış olduğu yüksek lisans tezinde, 4. ve 8. sınıf arasındaki 16 adet Fen ve Teknoloji ders kitabını incelemiş ve ders kitaplarında analojilerin sınırlılıklarının yeterince verilmediği sonucuna ulaşmıştır. Newton (2003), ilköğretim Fen Bilgisi kitaplarını incelediği çalışmasında 35 ders kitabını incelemiş, çoğunluğu basit türde olmak üzere toplam 92 analoji tespit etmiştir. Orgill ve Bodner (2006), yapmış oldukları çalışmada üniversite seviyesinde 8 Biyokimya ders kitabını incelemiş ve kitaplarda, sınırlılıkların açıklandığı analoji sayısının yetersiz olduğu sonucuna ulaşmışlardır. Thiele ve Treagust (1991), 8 Kimya kitabını inceledikleri çalışmalarında toplam 70 analoji tespit etmiş, bu analojilerin büyük bir kısmının basit türde olduğu sonucuna ulaşmışlardır. Demirci, Güler ve Yağbasan (2008), yapmış oldukları çalışmada 4, 5 ve 6. sınıf Fen ve Teknoloji; 7 ve 8. sınıf Fen Bilgisi ders kitaplarını incelemiş, tespit edilen toplam 89 analojinin önemli bir bölümünün basit türde olduğu sonucuna ulaşmışlardır.

Çalışmada ulaşılan bir diğer sonuç ise Sosyal Bilgiler ders kitaplarında kullanılan analojilerin öğrenme alanlarına homojen olarak dağılmadığıdır. Farklı sınıf düzeyindeki ders kitaplarında bazı öğrenme alanlarında hiç analojiye rastlanmamıştır. Buna karşın ders kitaplarında kullanılan analojiler bazı öğrenme alanlarında yoğunlaşmaktadır. Bu sonuçlar, ders kitaplarındaki analojilerin bilinçli ve sistematik şekilde kullanılmadı̆̆ı fikrini oluşturmuştur.

Ders kitapları sınıf seviyesine göre ele alındığında genel olarak sınıf seviyesi arttıkça analoji kullanım durumunun da artmakta olduğu belirlenmiş ve ders kitaplarında analoji 
366A, Şeyihoğlu, İ. E., Özgürbüz ve E, Torun/ Pamukkale Üniversitesi Eğitim Fakültesi Dergisi, 55, 347-375, 2022

kullanımı yetersiz bulunmuştur. Bununla birlikte 7. sınıf ders kitabında diğer kitaplara oranla analojilerin yoğunluk kazandığı ifade edilebilir. Bu durum 7. sınıf ders kitabı hazırlayıcılarının analoji kullanımına nispeten daha çok dikkat ettiği görüşünü oluşturmuştur. Buna ek olarak MEB tarafından yayınlanan ders kitaplarında özel yayınevine kıyasla daha çok analojiye yer verildiği de söylenebilir. Bu durum; MEB tarafından yayınlanan ders kitaplarının sayfa sayısının özel yayınevine oranla daha fazla olması sonucu analojilerin sayısal olarak daha çok olmasıyla veya analoji kullanımının sağladığı avantajların MEB yayınları ders kitabı yazarları tarafından nispeten daha çok dikkate alınmış olmasıyla açıklanabilir.

Analoji tekniğinde kaynağın öğrenciler tarafından bilinmesi önemli bir husustur (Harrison ve Treagust, 1993; Orgill ve Bodner, 2004; Treagust vd, 1994). Kaynağın öğrenciler tarafından bilinmediği durumlarda analoji amacına ulaşamaz, bu durum hedef kaynak ilişkisi kuramayan öğrencilerde kavram yanılgısına sebep olabilir (Cho, Kahle ve Norland 1985; Dikmenli ve Çardak, 2004; Gündüz, Yılmaz, Çimen ve Şen, 2017; Harrison ve Treagust, 1993; Heywood ve Parker, 1997; Kete, 2006). İncelenen ders kitaplarındaki konuyu somutlaştırmak için kullanılan görseller sadece hedefin tanıtımı için tasarlanmış olup kaynağın görseli şekle eklenmemiştir (Resim-1). Bu durum resimsel analoji olma potansiyeli taşıyan analojilerin sadece sözel analoji olarak nitelendirilmesine sebep olmuştur.
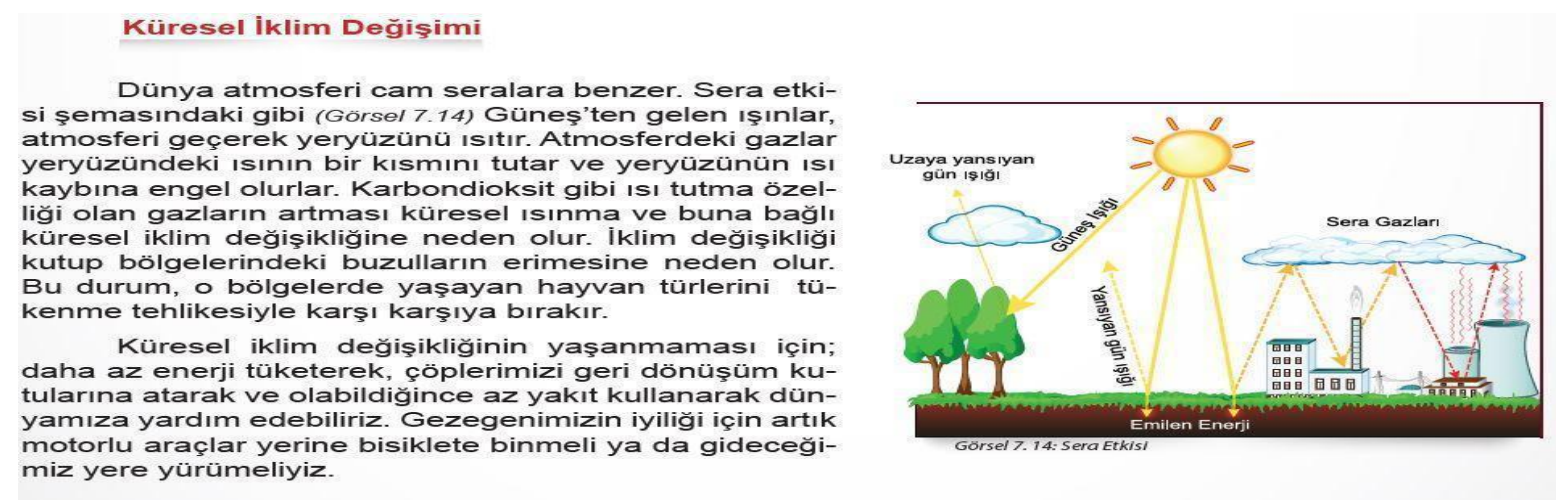

Resim 1. SB7-215

Ders kitaplarında kullanılan analojilerin çoğunlukla kişisel analoji olmaları, öğrencilerin kendilerini başka bir durum içinde hayal etmelerini gerektirmektedir. $\mathrm{Bu}$ durumun da öğrencilerde hayal gücünü geliştireceği düşünülmektedir. Bunun yanı sıra analojilerin kullanımında temel amaç, soyut ve karmaşık durumların somut ve anlaşılır örneklerle anlaşılmasını sağlamaktır (Akkuzu ve Akcay, 2011; Heywood, 2002). Bu 
A, Şeyihoğlu, İ. E., Özgürbüz ve E, Torun/ Pamukkale Üniversitesi Eğitim Fakültesi Dergisi, 55, 347-375, 2022367 anlamda ders kitaplarında örnek ilişkilendirme ve soyut bilgileri somutlaştırma adına yarar sağlayan farklı türlerde analojilere az yer verilmiş olması eksikliklerin öğretmen tarafindan giderilmesi gerektiği düşüncesini oluşturmuştur.

Genel olarak ders kitaplarıyla ilgili yapılan çalışmalar incelendiğinde ders kitaplarının eğitsel açıdan olumlu bulunduğu çalışmaların sınırlı sayıda olduğu göze çarpmaktadır (Demirci, 2007; İnal ve Mentiş Taş, 2011). Her ne kadar ders kitaplarını kısmen olumlu kısmen olumsuz bulan çalışmalara literatürde rastlansa da (Güven, 2010) genel olarak ders kitaplarının eğitsel açıdan yetersiz oldukları görüşü ağır basmaktadır. Literatürde ders kitapları ile ilgili yapılan araştırmaların büyük bir bölümünde ders kitaplarının eğitsel unsurların sunumu açısından yetersiz oldukları ve yapılandırmacı yaklaşıma uygun olmadıkları görüşüne vurgu yapılmaktadır (Türk ve Dursun, 2006; Gülcan, 2007; Çalışkan, 2006). Ayrıca ders kitaplarında öğrencilerin kavramları yapılandırmalarına yardımcı etkinlikler açısından eksik olduğu ve kavram yanılgılarına sebep olabilecek ifadelerin bulunduğu sonucuna varılmıştır (Karadüz, 2006; Özay ve Hasenekoğlu, 2006). Bu bağlamda yapılan çalışmada da literatürle paralel olarak Sosyal Bilgiler ders kitaplarında analojilerin basit düzeyde ve yetersiz kullanımına bağlı olarak eğitsel açıdan yeterli görülmediği ifade edilebilir.

Bu çalışma, araştırmanın amacı çerçevesinde incelenen ve 2020-2021 eğitim öğretim döneminde Talim Terbiye Kurulu Başkanlığı tarafından onaylanan ve derslerde kullanılan 4.5.6 ve 7. Sosyal Bilgiler ders kitaplarıyla sınırlıdır. Sosyal Bilgiler ders kitaplarında yer alan analojilerin nicelik ve nitelik açısından incelendiği bu çalışmanın, ders kitaplarında analoji kullanımının arttırılması ve niteliğinin zenginleştirilmesi için öneri sunma adına firsat sağladığı düşünülmektedir.

\section{Öneriler}

$\mathrm{Bu}$ sonuçlar doğrultusunda aşağıdaki önerilerde bulunulabilir:

- Sosyal Bilgiler ders kitapları genelinde analojilere nadiren yer verildiği tespit edilmiştir. Somutlaştırmayı sağlamak, öğrenmeyi kolaylaştırmak amacı ile ders kitaplarında kullanılan analoji sayısı artırılabilir.

- Öğretmenlere, söz konusu eksikliği fark edebilecek ve giderebilecek seviyeye ulaşabilmeleri için hizmet öncesinde ve içinde çeşitli eğitim firsatları sunulabilir. 
368A, Şeyihoğlu, İ. E., Özgürbüz ve E, Torun/ Pamukkale Üniversitesi Eğitim Fakültesi Dergisi, 55, 347-375, 2022

- Sosyal Bilgiler ders kitaplarında analojilere homojen ve dengeli olarak yer verilmediğgi, bazı öğrenme alanlarında yığıldığı bazılarında ise hiç kullanılmadığı tespit edilmiştir. Analojiler öğrenme alanları bazında dengeli ve homojen kullanılabilir.

- Sosyal Bilgiler ders kitaplarında yer alan analojilerin çoğu kişiseldir ve basit düzeydedir. Bu analojilerin zenginlik düzeyleri artırılarak nitelikleri geliştirilebilir.

- $\quad$ Sosyal Bilgiler ders kitaplarında kullanılan analojilerde kaynak ve hedef arasındaki ilişki çoğunlukla temel düzeyde verilmiştir. Analojileri daha etkili kılma adına kaynak ve hedef arasındaki ilişkinin sınırlılık ve benzemeyen yönleri de ön plana çıkarılabilir.

- Sosyal Bilgiler ders kitaplarındaki analojilerin görsellerle desteklenmesi zayıf bulunmuş, sadece hedefin tanıtımı için tasarlandığı tespit edilmiştir. Analojilerde hedef ve kaynak arasındaki ilişkinin daha anlaşılır hale getirilmesi amacıyla her iki taraf için de resimlerin kullanılması önerilmektedir. $\mathrm{Bu}$ sebeple sunumuna göre analojiler resimlerle desteklenebilir. Ayrıca sözel analojilerin doğru şekilde anlaşılıp anlaşılmadığını kontrol eden çalışmalar da yapılabilir.

Etik Kurul İzin Bilgisi: Bu araştırma, Trabzon Üniversitesi Sosyal ve Beşeri Bilimler Araştırma ve Etik Kurulu'nun 13/10/2020 tarihli, 81614018-000-E.405 sayılı kararl ile alınan izinle yürütülmüştür.

Yazar Çıkar Çatışması Bilgisi: Bu çalışmada yazarlar arasında çıkar çatışması bulunmamaktadır.

Yazar Katkısı: Yazarlar çalışmaya eşit oranda katkı sağlamıştır. 
A, Şeyihoğlu, İ. E., Özgürbüz ve E, Torun/ Pamukkale Üniversitesi Eğitim Fakültesi Dergisi, 55, 347-375, 2022369

\section{Kaynakça}

Adnan, Y. A. (2015). Ortaöğretim 12. sinıf biyoloji ders kitabinda kullanılan analojiler üzerine bir araştırma. (Yüksek lisans tezi). Yükseköğretim Kurulu Ulusal Tez Merkezi'nden edinilmiştir. (Tez No. 407549).

Akkuzu, N. ve Akcay, H. (2011). An effective model to increase student attitude and Achievement: Nnarrative including analogies. US-China Education Review, 5, 612623.

Akman, Ö. ve Bastık, U. (2016). Sosyal bilgiler ders kitaplarında ihtilaflı konular içerisinde yer alan "aile" 'kavramının incelenmesi: bir içerik analizi. Trakya Üniversitesi Eğitim Fakültesi Dergisi, 6(2).

Atav, E., Erdem, E., Yılmaz, A. ve Gücüm, B. (2004). Enzimler konusunun anlamlı öğrenilmesinde analojiler oluşturmanın etkisi. Hacettepe Üniversitesi Ĕ̆itim Fakültesi Dergisi, (27), 21-29.

Aydemir, M. (2017). Ortaokul sosyal bilgiler ders kitaplarının ortaokul sosyal bilgiler dersi öğretim programında yer alan beceriler açısından incelenmesi. Uluslararası Güncel Ĕ̌itim Araştırmaları Dergisi, 3(2), 1-17.

Azizoğlu, N., Çamurcu, M. ve Kırtak-Ad, V. N. (2014). Ortaöğretim fizik ders kitaplarında analojilerin kullanımı: Belirleme ve sınıflandırma çalışması. Journal of Turkish Science Education, 11(2), 36-59.

Barton, K. ve Smith, L. (2000). Themes or motifs? Aiming for coherence through interdisciplinary outline. The Reading Teacher, 54, (1), 54-63.

Baş, K. (2020). Sosyal bilgiler ders kitaplarında sanat kavramının ve sanat içerikli konuların yeri. Akdeniz Eğitim Araştırmaları Dergisi, 14(31), 668-691.

Bayazit, İ. (2011). Öğretmen adaylarının matematik öğretiminde analoji kullanımları konusundaki görüş ve yeterlilikleri. Selçuk Üniversitesi Ahmet Keleşoğlu Ĕğitim Fakültesi Dergisi, (31), 139-158.

Ceyhan, E. ve Yiğit, B. (2005). Konu alanı ders kitabı incelemesi. Ankara: Anı Yayıncılık.

Cho, H.H., Kahle, J.B. ve Norland, F.H. (1985). An 1nvestigation of high school biology textbooks as sources of misconceptions and difficulties in genetics and some suggestions for teaching genetics. Science Education, 69(5), 707-719. 
370A, Şeyihoğlu, İ. E., Özgürbüz ve E, Torun/ Pamukkale Üniversitesi Eğitim Fakültesi Dergisi, 55, 347-375, 2022

Curtis, R. V. ve Reigeluth, C. M. (1984). The use of analogies in written text. Instructional Science, (13), 99-117.

Çalışkan, N. (2006). Türkiye'deki ortaöğretim edebiyat ders kitapları üzerine edebiyat eğitimi açısından bir değerlendirme. Milli Eğitim Dergisi, 34 (169), 355-364.

Çeken, R. (2011). İlköğretim fen ve teknoloji ders kitaplarında kalp ve akciğer ile ilgili şekillerin analizi. Kastamonu Ĕ̌itim Dergisi, 19 (3), 903-912.

Çepni, S. (2014). Araştırma ve proje çalışmalarına giriş. Trabzon: Celepler Matbaacılık.

Çıray, F. (2010). İlköğretim disiplinler arası analoji tabanlı öğretimin öğrencilerin ögrenme düzeylerine etkisi. (Yayınlanmamış yüksek lisans tezi). Anadolu Üniversitesi Eğitim Bilimleri Enstitüsü, Eskişehir.

Demir, S., Önen, F. ve Şahin, F. (2011). Fen bilgisi öğretmen adaylarının bakış açısıyla analojiler. Necatibey Eğitim Fakültesi Elektronik Fen ve Matematik Ĕ̈itimi Dergisi, $5(2), 86-114$.

Demir, Y. ve Atasoy, E. (2018). 5. sınıf sosyal bilgiler ders kitabının (2017) değerlendirilmesi. Uludă̆ Üniversitesi Eğitim Fakültesi Dergisi, 31(2), 753-780.

Demirci Güler, M. P. (2007). Fen öğretiminde kullanılan analojiler, analoji kullanımının ögrenci başarısı, tutumu ve bilginin kalıcılı̆̆ına etkisinin araştırılması. (Doktora tezi) Yükseköğretim Kurulu Ulusal Tez Merkezi’nden edinilmiştir. (Tez No. 211828).

Demirci Güler, P. ve Yağbasan, R. (2008). Fen ve Teknoloji ders kitaplarında kullanılan analojilerin ve analojilere ilişkin sorunların betimlenmesi. İnönü Üniversitesi Ĕgitim Fakültesi Dergisi, 9(16), 105-122.

Demirci, C. (2007). Fen bilgisi 6, 7 ve 8. sınıf ders kitaplarının değerlendirilmesi. Hacettepe Üniversitesi Ĕ̆itim Fakültesi Dergisi, 33, 108-119.

Dikmenli, M. (2015). A study on analogies used in new ninth grade biology textbook. AsiaPacific Forum on Science Learning and Teaching, 16(1), 1-20.

Dikmenli, M. ve Çardak, O. (2004). A Study on misconceptions in the 9th grade high school biology textbooks. Eurasian Journal of Educational Research, (17), 130-141.

Dilber, R. (2006). Fizik öğretiminde analoji kullanımının ve kavramsal değişim metinlerinin kavram yanılgılarının giderilmesine ve ögrrenci başarısına etkisinin araştırılması. 
A, Şeyihoğlu, İ. E., Özgürbüz ve E, Torun/ Pamukkale Üniversitesi Eğitim Fakültesi Dergisi, 55, 347-375, 2022371

(Doktora tezi). Yükseköğretim Kurulu Ulusal Tez Merkezi’nden edinilmişstir. (Tez No. 181511).

Duit, R. (1991). On the role of analogies and metaphors in learning science. Science Education, 75(6), 649-672.

Duman, N. (2016). An Example of the Use of Personal Analogy in Teaching Geography: If I Were a Mineral. Educational Research and Reviews, 11(8), 721-731.

Duman, N., Özgürbüz, İ., ve Şeyihoğlu, A. (2020). Reflections of the teaching-withanalogies model (TWA) on the teaching of geography. OPUS Uluslararası Toplum Araştırmaları Dergisi, 16(29), 1642-1665.

Ekici, E., Ekici, F. ve Aydın, F. (2007). Fen bilgisi derslerinde benzeşimlerin (analoji) kullanılabilirliğine ilişkin öğretmen adaylarının görüşleri ve örnekleri. Ahi Evran Üniversitesi Kırşehir Eğitim Fakültesi Dergisi, 8 (1), 95-113.

Gedik Demirkaya, H. (2008). Sosyal bilgiler ders kitaplarında güncel konular. Türkiye Sosyal Araştırmalar Dergisi, (1), 117-134.

Glynn, S. M., \& Takahashi, T. (1998). Learning from analogy-enhanced science text. Journal of Research in Science Teaching, 35(10), 1129-1149.

Gülcan, B. K. (2021). Fen lisesi biyoloji ders kitaplarındaki metaforların, analojilerin ve teleolojilerin incelenmesi. (Yüksek lisans tezi). Yükseköğretim Kurulu Ulusal Tez Merkezi'nden edinilmiştir. (Tez No. 675299).

Gülcan, M. G. (2007). İlköğretim Sosyal Bilgiler 5. sınıf ders kitabı inceleme (görsel ve eğitsel tasarım). Çukurova Üniversitesi Eğitim Fakültesi 3. Sosyal Bilimler Eğitimi Kongresi, 305-311.

Gülersoy, A. E. (2012). İdeal ders kitabıi arayıişıinda sosyal bilgiler ders kitaplarıinıin bazii özellikler açiisiindan incelenmesi. International Journal of New Trends in Arts, Sports \& Science Education, 2(1), 8-26.

Gürkan, B. ve Doğanay, A. (2016). Sosyal bilgiler dersinde disiplinler arası öğretim yaklaşımına dayalı analoji tekniği uygulamalarının kavram gelişimine etkisi: bir durum çalışması, Turkish Studies, 11(16), 395-416.

Güven, S. (2010). İlköğretim hayat bilgisi dersi ders ve öğrenci çalışma kitaplarının öğretmen görüşlerine göre değerlendirilmesi. Eğitim ve Bilim, 35 (156), 84-95. 
372A, Şeyihoğlu, İ. E., Özgürbüz ve E, Torun/ Pamukkale Üniversitesi Eğitim Fakültesi Dergisi, 55, 347-375, 2022

Harman, G., ve Çökelez, A. (2017). Öğretimde analoji kullanımının etkisi: lamba parlaklığını nasıl değiştirebiliriz? Necatibey Eğitim Fakültesi Elektronik Fen ve Matematik Ĕ̈itimi Dergisi, 12(1), 361-391.

Harrison, A. G., \& Treagust, D. F. (1993). Teaching with analogies: A case study in grade-10 optics. Journal of Research In Science Teaching, 30(10), 1291-1307.

Heywood, D. (2002). The place of analogies in science education. Campridge Journal of Education, 32 (2), 64-75.

Hıdır, M. ve Didiş Körhasan, N. (2018). Fen ders kitaplarındaki analojilerin ve fen eğitimcilerinin analojilerin etkili kullanımına ilişkin görüşlerinin incelenmesi. Necatibey Eğitim Fakültesi Elektronik Fen ve Matematik Eğitimi Dergisi, 12 (2).

İnal, N. ve Mentiş Taş, A. (2011). İlköğretim 3. sınıf hayat bilgisi ders kitaplarına ilişkin öğretmen görüşleri. Selçuk Üniversitesi Ahmet Keleşoğlu Eğitim Fakültesi Dergisi, (31), 279-295.

Kaçar, T. ve Bulut, B. (2020). Sosyal bilgiler öğretim programı ve 4-7. sınıf sosyal bilgiler ders kitaplarının coğrafya kavramları bağlamında değerlendirilmesi. Kahramanmaraş Sütçü İmam Üniversitesi Sosyal Bilimler Dergisi, 17(2), 652-679.

Kaptan, F. ve Arslan, B. (2002). Fen öğretiminde soru-cevap tekniği ile analoji tekniğinin karşılaştırılması. V. Ulusal Fen Bilimleri ve Matematik Ĕ̆itimi Kongresi, 183-189.

Karadeniz, S. (2017). Ortaokul matematik ders kitaplarında kullanılan analojilerin incelenmesi. (Yüksek lisans tezi). Yükseköğretim Kurulu Ulusal Tez Merkezi’nden edinilmiştir. (Tez No. 476119)

Karadüz, A. (2006). İlköğretim Türkçe dilbilgisi kitaplarının ‘öğreticilik’ kavramı bağlamında eleştirisi. Sosyal Bilimler Enstitüsü Dergisi, 2 (21), 13-31.

Karasu Avc1, ve Faiz, M. (2018). 4. ve 5. sınıf sosyal bilgiler ders kitapları "etkin vatandaşlık” öğrenme alanında yer alan becerilerin ve değerlerin incelenmesi. Uluslararası Sosyal Bilgilerde Yeni Yaklaşımlar Dergisi, 2(1), 1-21.

Kaya, E. (2010). Fen ve teknoloji ders kitaplarında ve ögretim programındaki benzetmelerin gruplandırılması. (Yüksek lisans tezi). Yükseköğretim Kurulu Ulusal Tez Merkezi'nden edinilmiştir. (Tez No. 259886). 
A, Şeyihoğlu, İ. E., Özgürbüz ve E, Torun/ Pamukkale Üniversitesi Eğitim Fakültesi Dergisi, 55, 347-375, 2022373

Kaymakcı, S. (2013). Sosyal bilgiler ders kitaplarinda sözlü ve yazillii edebî türlerin kullaniim durumu. Dicle Üniversitesi Ziya Gökalp Eğitim Fakültesi Dergisi, (20), 230-255.

Kete, R. (2006). 6. sınıf fen bilgisi biyoloji konularında kavram yanılgıları. Dokuz Eylül Üniversitesi Buca Eğitim Fakültesi Dergisi, 19, 63-70.

Kırtak Ad, V. N., ve Tüfekçi, E. (2021). Ortaöğretim fizik ders kitaplarında yer alan analojiler: belirleme, sınıfiniflandirma ve karşılaştırma çalışması. International Journal of New Trends in Arts, Sports \& Science Education, 10(2), 130-144.

Kobak, R. (2013). Ortaöğretim kimya ders kitaplarında yer alan analojilerin analog-hedef haritalama yapılarının incelenmesi. (Yüksek lisans tezi). Yükseköğretim Kurulu Ulusal Tez Merkezi’nden edinilmiştir. (Tez No. 324650).

Kolaç, E. (2003). İlköğretim dördüncü sınıf Türkçe ders kitaplarının öğretmen görüşlerine dayalı olarak değerlendirilmesi. Uludă̆ Üniversitesi Eğitim Fakültesi Dergisi, 17 (1), 105-137.

Köseoğlu, F., Atasoy, B., Kavak, N., Akkuş, H., Budak, E., Tümay, H., Kadayıfçı, H. ve Taşdelen, U. (2003). Bir fen ders kitabı nasıl olmalı. Ankara: Asil Yayın Dağıtım.

Köymen, Ü. (2000). Güdüleyici Öğrenme. (1.bs). A. Şimşek (Ed.). Sinıfta Demokrasi, içinde (s.111-145), Ankara: Eğitim Sen Yayınları.

Malatyalı, E. ve Y1lmaz, K. (2010). Yapılandırmacı öğrenme sürecinde kavramlar ve önemi: Kavramların pedagojik açıdan incelenmesi. Uluslararası Sosyal Araştırmalar Dergisi, 3 (14), 320-332.

Milli Eğitim Bakanlı̆̆ı, (2006). Mevzuat, ders kitapları ile eğitim araçlarının incelenmesi ve değerlendirilmesine ilişkin yönerge., Tebliğler Dergisi, Ekim.

Milli Eğitim Bakanlığı, (2012). Talim ve terbiye kurulu başkanlığı, ilköğretim sosyal bilgiler ögretim programı (4. ve 5. sınıflar). Ankara: Milli Eğitim Bakanlığı.

Newton, L. D. (2003). The occurence of analogies in elementary school science books. Instructional Science, (31), 353-375.

Orgill, M. K. \& Bodner, G. M. (2006). An analysis of the effectiveness of analogy use in college-level biochemistry textbooks. Journal of Resarch In Science Teaching, 43 (10), 1040-1060. 
374A, Şeyihoğlu, İ. E., Özgürbüz ve E, Torun/ Pamukkale Üniversitesi Eğitim Fakültesi Dergisi, 55, 347-375, 2022

Özay, E. ve Hasenekoğlu, İ. (2006). Biyoloji ders kitapları üzerine yapılan çalışmalar. Atatürk Üniversitesi Bayburt Ĕ̈itim Fakültesi Dergisi, 1 (1), 68-79.

Öztürk, F., N. ve Aydın, A. (2013). 7. sınıf fen ve teknoloji müfredat modülasyonu: öğretmenlerden gelen özgün anlamlar/analojiler. International Journal of Social Science, 6 (1), 299-309.

Reeves, T.C., Herrington, J.\& Oliver, R. (2002). Authentic activities and online learning. Proceedings of the 25th HERDSA Annual Conference, Perth, Western Australia, 710 July 562 .

Schreglmann, S. (2019). Ortaöğretim bilgisayar bilimi ders kitabındaki analojilerin incelenmesi. Ilköğretim Online, 18 (4), 1641-1651.

Senemoğlu, N. (2011). Gelişim öğrenme ve öğretim kuramdan uygulamaya. Ankara: Pegem A Yayıncilik.

Şahin, F. (2010). Okul Öncesinde Kavram Haritaları-Analojiler ve Deney, R. Zembat, (Ed.), Okul Öncesinde Özel Öğretim Yöntemleri, içinde (s. 285-314), Ankara: An1 Yayıncilik.

Şaşmaz Ören, F., Ormancı, Ü., Babacan, T., Çiçek, T. ve Koparan, S. (2010). Analoji ve araştırma temelli öğrenme yaklaşımına dayalı rehber materyal uygulaması ile buna yönelik öğrenci görüşleri. Batı Anadolu Ĕ̆itim Bilimleri Dergisi, 1 (1), 33-53.

Şeyihoğlu, A. ve Özgürbüz, İ. E. (2015). Analysis of analogies in geography textbooks. Education and $\quad$ Science. (40)179, 163-179. doi: http://dx.doi.org/10.15390/EB.2015.2609

Şeyihoğlu, A., Akbaş, Y., Kartal, A. (2012). Uygulama örnekleri ile coğrafya ĕ̆itiminde kavram ve zihin haritalart, Ankara: Pegem Akademi.

Şimşek, A. (2006). Kavramların öğretimi (1. bs.). A. Şimşek (Ed.), İçerik Türlerine Dayalı Öğretim, içinde (ss. 27- 70). Ankara: Nobel Yayıncılık.

Tezcan, H. ve Seyitoğlu, B. (2007). Lise kimya ders kitaplarının analojik açıdan incelenmesi. Milli Ĕ̈itim Dergisi, 36 (174), 282-292.

Thiele, R. B., \& Treagust, D. F. (1994). An interpretive examination of high school chemistry teachers' analogical explanations. Journal of Research in Science Teaching, 31(3), 227-242. 
A, Şeyihoğlu, İ. E., Özgürbüz ve E, Torun/ Pamukkale Üniversitesi Eğitim Fakültesi Dergisi, 55, 347-375, 2022375

Thiele, R.B. \& Treagust, D. F. (1991). Using analogies to aid understanding in secondary chemistry education. Educational Resources Information, Center (ERİC).

Tufan, M. (2019). Kimya ders kitaplarındaki ve kimya öğretmenlerinin geliştirdikleri analojilerin incelenmesi. (Yüksek lisans tezi). Yükseköğretim Kurulu Ulusal Tez Merkezi'nden edinilmiştir. (Tez No. 583568).

Türk, M. S. ve Dursun, B. (2006). MEB tarafından ortaöğretim kurumlarında okutulan ders kitaplarının biçimsel açıdan incelenmesi. Atatürk Üniversitesi Bayburt Ĕ̈itim Fakültesi Dergisi, 1(1), 20-36.

Ülgen, G. (2001). Kavram geliştirme. Ankara: Pegem A Yayıncılık.

Yıldırım, A. ve Şimşek, H. (2016). Sosyal bilimlerde nitel araştırma yöntemleri. Ankara: Seçkin Yayıncılık.

Yılmaz, K. ve Çeltikçi, C. (2013). İlköğretim 3. sınıf öğrencilerine soyut ve çok boyutlu kavramların kazandırılması: Bir eylem araştırması. Turkish Studies-International Periodical for the Languages, Literature and History of Turkish or Turkic, 8(6), 895924. 


\title{
Analysis of Analogies in Social Studies
}

\section{Textbooks in Primary School Grades 4,5,6 and 7}

\section{Ayşegül ŞEYİHOĞLU* İbrahim Emrah ÖZGÜRBÜZ ${ }^{* *}$ Elif TORUN***}

- Received: 24.10.2021 • Accepted: 04.02.2022 • Online First: 04.02.2022

\begin{abstract}
This study examines the amount and types of analogies in the Social Studies textbooks used in the 4th, 5th, 6th, and 7th-grades in primary education in the 2020-2021 academic year. In this qualitative study, data were compiled using the document analysis technique, and the Social Studies textbooks at the 4th, 5th, 6th, and 7th grades were examined as documents. In this study, content analysis was used to identify analogies in textbooks, descriptive analysis was used to classify analogies according to their types and learning areas, and the findings were tabulated. As a result of the research, it has been determined that the analogies in the Social Studies textbooks are mainly of the "personal analogy" type, and the utilization of analogies increases as the grade level increases. In addition, it has been concluded that analogies are not homogeneously distributed across learning areas, and they are not at a sufficient level in terms of quantity and quality. As a result of the study, suggestions were made within the scope of Social Studies Education, such as increasing awareness about analogies and encouraging the use of analogies, enriching existing analogies by presenting them with visuals and aspects to be improved.
\end{abstract}

Keywords: analogy, social studies teaching, social studies textbooks

\section{Cited:}

Şeyihoğlu, A., Özgürbüz, İ.E., \& Torun, E. (2022). Analysis of analogies in social studies textbooks in primary school grades 4,5,6, and 7. Pamukkale University Journal of Education, 55, 347375.doi: 10.9779.pauefd.1014279

\footnotetext{
* Prof. Dr., Trabzon University, Orcid: 0000-0001-8143-3753, asegulseyihoglu@ gmail.com

** PhD Candidate, Atatürk University, Orcid: 0000-0002-5849-0511 ozgurbuze@ gmail.com

*** Res. Asst., Trabzon University, Orcid: 0000-0003-3013-3691, eliftorun0325@gmail.com
} 


\section{Introduction}

Concepts that form the basis of the cognitive structure of the individual play an important role in the realization of effective and permanent learning (Malatyalı \& Y1lmaz, 2010). Concepts learned, especially in the primary and secondary education periods, are the first steps in lifelong learning (Ülgen, 2001). It is also important to learn the concepts correctly, meaningfully, and permanently in Social Studies. In this context, it is important to ensure meaningful learning by harmonizing new information with prior knowledge, increasing the quality of education, concretizing information, preventing misconceptions, which is one of the most important factors affecting learning, and ensuring that concepts are learned correctly. As a matter of fact, Şimşek (2006) noted that performing learning activities on known and familiar elements contributes to the perception of knowledge as meaningful. In addition, Köymen (2000) stated that imparting abstract knowledge starting from the previously known elements increases student motivation and creates a sense of curiosity. Since concrete concepts are more easily visualized in mind, learners make sense of concrete concepts easier and faster than abstract concepts. Gürkan and Doğanay (2016) emphasize that teaching abstract concepts to students who are not in the abstract operational stage should be based on concrete elements. From this point of view, it can be stated that analogies, which are one of the most important techniques used in concretizing abstract concepts in Social Studies education (Atav, Erdem, Yılmaz, \& Gücüm, 2004; Bayazit, 2011; Curtis and Reigeluth, 1984; Demir, Önen and Şahin, 2011; Ekici, Ekici \& Aydın, 2007) can be used, because analogies are an innovative teaching technique that facilitates the teaching, development, and mental representation of scientific concepts (Demirci-Güler, 2007). In addition, analogies enable learners to make inferences about the unknown concept based on known concepts and features of the concept (Duman, Özgürbüz, \& Şeyihoğlu, 2020). Various difficulties can be experienced during instructional activities, especially in the parts where the students are imparted to invisible events and facts.

Moreover, when this process is monotonous, it is inevitable for the students to lose interest in the lesson. At this point, the analogy is an effective tool that facilitates knowledge transfer by establishing a link between the new concept that is unfamiliar with the help of previous learning in the student's cognitive structure (Tezcan \& Seyitoğlu, 2007). In other words, the unknown concept is explained by starting from the known concept. In this process, the known concept is described as a "source (tool)", while the unknown concept is described as a "target (subject)" (Glynn \& Takahashi, 1998; Şaşmaz Ören, Ormanc1, 
A, Şeyihoğlu, İ. E., Özgürbüz \& E, Torun / Pamukkale University Journal of Education, 55, 347-375, 2022

Babacan, Çiçek, \& Koparan, 2010). Analogies foster concretizing and make abstract elements understandable by establishing a relationship between the known concept and the unknown concept.

In addition to all these, analogies are one of the effective techniques for learning new concepts and drawing conclusions, and they offer a sound learning and teaching environment due to their advantages in problem-solving, explaining, and creating a suitable environment for debate activities (Dilber, 2006). Analogy are important for teaching activities in associating a concept with more than one discipline rather than a single discipline, enabling inter-conceptual thinking, increasing student motivation (Barton \& Smith, 2000; Dikmenli, 2015; Duit, 1991; Gülcan, 2021; Harrison \& Treagust, 1993; Kaptan \& Arslan, 2002; Köseoğlu, et al., 2003; Reeves, Herrington, and Oliver, 2002). Analogies reduce the burden on memory by enabling large and complex information to be placed in the mind with shorter codes through association, and the connection established between known and unknown knowledge leads to the adaptation of knowledge to different areas (Bayazit, 2011). Çıray (2010) found that analogy-based instruction increased academic success and learning gains. In addition, Gürkan and Doğanay (2016) found that analogies contributed to conceptual understanding by delineating concepts' attributes. Thus, a meaningful construct is created in learners' minds via integrating previous knowledge with new knowledge. Analogies, which offer several instructional advantages, are very functional in terms of nurturing interest and motivation, enhancing visual quality (Harman \& Çökelez, 2017), and facilitating learning through concretizing abstract and complex situations (Akkuzu \& Akcay, 2011; Heywood, 2002). In addition, analogies are important tools that reduce cognitive load by transferring information to long-term memory with shorter codes, facilitating remembering, enable information to be used in different areas (Bayazit, 2011; Şeyihoğlu \& Özgürbüz, 2015). In short, they are important tools that make learning stronger depending on quality (Duman et al., 2020).

There are different classifications of analogies in the literature. Analogies can generally be handled under four headings simple, enriched, extended, and personal analogies. Simple analogies involve a direct comparison of one thing to another (Şahin, 2010). Examples of this type of analogy include the analogy of the Big Bear constellation in Turkish (Charles' Wain), to an inclined coffee pot (SB-4 p.64), a spinner is analogized to a pear (SB-4 p.47), the horon is analogized to a wavy sea (SB-5 p.46), the coming together of individuals with different characteristics is analogized to the motifs in a rug (SB-6 p.32), the 
atmosphere is resembled to glass greenhouses (SB-7 p.215). Enriched analogies are the type of analogies in which the relationship between the target and the source is explained, or the limitations or dissimilarities between the target and the source are given. The expression, "Can we compare our country to a flower garden? What can we say if we think of the garden as the sum of the differences that make up society? (SB-6 p.27) exemplifies the enriched analogy type. In extended analogies, either a single tool is used to teach more than one subject, or different tools are used to teach a single subject (Curtis \& Reigeluth, 1984). "When we look at the patterns on the rugs one by one, they do not make sense. When patterns come together, they express richness. While colors create patterns, patterns create motifs, and motifs create rugs, differences create a form of art” (SB-6 p.32), an example of the expanded analogy. On the other hand, personal analogies help students learn abstract concepts by associating them with their own worldview (Duman, 2016). A personal analogy is a type of analogy in which the student plays imagery or physical role by putting himself in the place of the target object, person, or concepts to be taught (Thiele \& Treagust, 1991). "If you were a tourist visiting Turkey, what souvenirs you would take to your country?" (SB-4 p.190) The question is an example of a personal analogy. The types of analogies are given schematically in Figure 1.

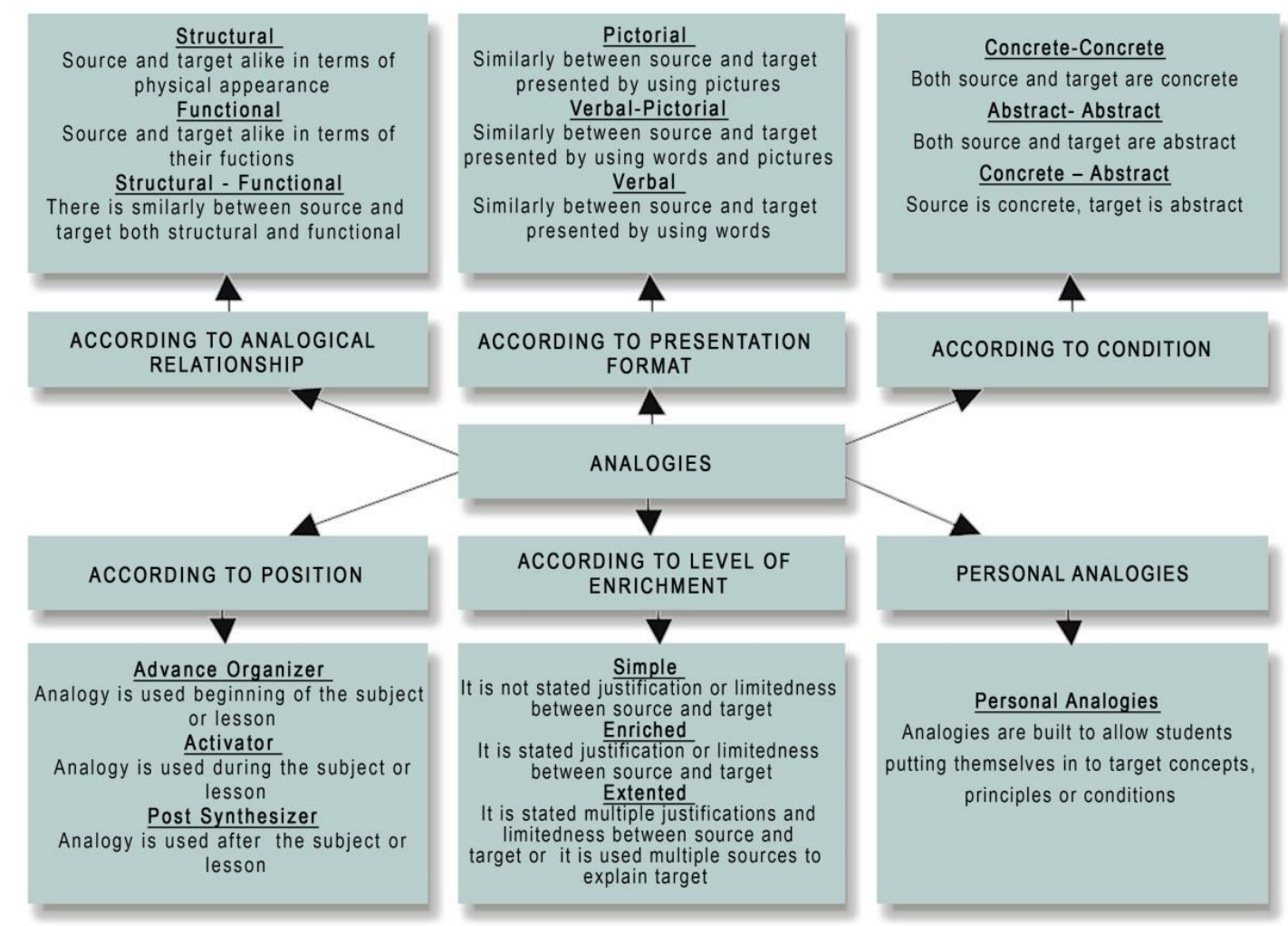

Figure 1. Types of analogy (Şeyihoğlu \& Özgürbüz, 2015) 
One of the two important variables that should be taken into consideration when using the analogy technique in educational processes is teacher characteristics, and the other is textbooks (Hıdır \& Didiş Körhasan, 2018). Since the individual characteristics and competencies of the teachers are different from each other, the use of analogies in their lessons also varies. However, textbooks are the main resources that all teachers and students can easily access and do not change according to the situation. It is still an accepted fact that books, which provide the opportunity to design many activities and guide the teacher, have an important place in the classroom (Ceyhan \& Yiğit, 2005; Çalışkan, 2006; Ceken, 2011). In addition, the importance of textbooks increases even more in the primary education period, especially when cognitive and affective development is shaped. Textbooks play an important role in raising democratic, contemporary, free generations that have advanced scientific thinking skills and are aware of and fulfill their responsibilities towards society (Kolaç, 2003). In addition, the importance of textbooks increases even more in the primary education period, when cognitive and affective development is shaped.

Textbooks play an important role in raising democratic, modern, free generations, have advanced scientific thinking skills, and know and fulfill their responsibilities towards society (Kolaç, 2003). However, textbooks, which are one of the most important materials in the implementation of curricula, are expected to have certain qualities. Y1lmaz and Çeltikçi (2013) emphasize that textbooks should have visual elements that make it easier for students to represent information in their minds and be helpful and supportive in teaching. Furthermore, textbooks should be resources that allow the structuring of the information in the mind of the student and follow a method that goes "from close to far, from simple to complex, from easy to difficult, and from concrete to abstract" (MNE, 2006), in which abstract elements are explained through concretization (Senemoğlu, 2011). The analogy is one of the most important techniques that will facilitate the fulfillment of these functions in the textbooks and, at the same time, enable meaningful learning to take place.

When the literature is examined, it is seen that the textbooks are studied many times from different perspectives for different purposes. Social Studies textbooks have been examined to detect how various skills (Aydemir, 2017; Karasu Avc1 \& Faiz, 2018), concepts (Akman \& Bastık, 2016; Baş, 2020; Kaçar \& Bulut, 2020), and subjects (Gedik Demirkaya, 2008) are handled. In addition, various classifications were evaluated in terms of content analysis (Demir \& Atasoy, 2018; Kaymakc1, 2013) and compatibility with the program (Gülersoy, 2012). Although there are many studies examining analogies in textbooks in the 
literature review, no study so far has examined Social Studies textbooks in terms of analogies. Although many studies examine analogies in textbooks in the literature review, no study has been found in which Social Studies textbooks are handled in terms of analogies. In this context, the studies on analogies in the textbooks are mostly Chemistry (Kobak, 2013; Orgill \& Bodner 2006; Thiele \& Treagust 1994; Tufan 2019), Science (Demirci-Güler and Yağbasan, 2008; Glynn \& Takahashi 1998; Hıdır \& Didiş Körhasan, 2018; Öztürk \& Aydın 2013), Physics (Azizoğlu, Çamurcu and Kırtak-Ad, 2014; Kırtak-Ad \& Tüfekçi, 2021), Biology (Adnan, 2015; Gülcan, 2021) Mathematics (Karadeniz, 2017), Computer, (Schreglmann, 2019), Geography (Şeyihoğlu \& Özgürbüz, 2015). In this context, the studies in which analogies are discussed in the textbooks are determined to be mostly on Chemistry (Kobak, 2013; Orgill \& Bodner 2006; Thiele \& Treagust 1994; Tufan 2019), Science (Demirci-Güler \& Yağbasan, 2008; Glynn \& Takahashi 1998; Hıdır \& Didiş Körhasan, 2018; Öztürk \& Aydın 2013), Physics (Azizoğlu, Çamurcu \& Kırtak-Ad, 2014; Kırtak-Ad \& Tüfekçi, 2021), Biology (Adnan, 2015; Gülcan, 2021) Mathematics (Karadeniz, 2017), Computer, (Schreglmann) , 2019), Geography (Şeyihoğlu and Özgürbüz, 2015). There is a case study in which analogies are handled specifically in Social Studies (Gürkan \& Doğanay, 2016). When the literature is examined in general, it has been determined that the current studies are mostly studies in the field of science. However, no study examined analogies in the Social Studies textbooks within the scope of 4-7 grades, which are the focus of this study. With its comprehensive curriculum, Social Studies is also one of the pivotal courses. In other words, it is one of the basic courses in which the scientific foundations of many branches are laid down. Social studies education includes concrete information and concepts as well as abstract information and concepts. It can be difficult for children to construct this abstract information completely and correctly. For this reason, the use of analogy in the Social Studies course has an important place in detecting and eliminating misconceptions, simplifying and concretizing concepts according to the teaching principles, and associating the subject with resources from life. Examining textbooks, one of the supplementary materials that teachers use the most, in terms of analogies, can significantly contribute. It is not expected that each teacher will have the same ability to create analogies and present examples. In this context, studies that aim to increase the quantity and quality of the analogies used in the textbooks gain more importance. Considering the benefits of the analogy technique, it is thought that it will be useful to determine its use in Social Studies textbooks and make suggestions based on this. For this reason, the problem statement of the research is: "What are the quality and quantity 
of analogies in grades 4, 5, 6 and-7Social Studies textbooks?" In line with this, the following sub-problems were created concerning the problem sentence.

- How are analogies used in grade 4, 5, 6, and -7social studies textbooks, and how are they distributed across different types of analogies?

- How are the types of analogies the textbooks in 4-7th grade Social Studies textbooks distributed across learning areas, and how do learning areas compare in terms of analogy types?

\section{Method}

In this study, a qualitative approach was adopted, and the data were examined with the document analysis technique. Document analysis is the process of coding and examining the relevant documents according to a certain system (Çepni, 2014). The document analysis technique allows making inferences about the general trend by examining the available resources in the field. Presenting the general trend in the existing resources may provide an opportunity to reveal the deficiencies and needs in the field, present alternative and different ideas, and integrate them (Çepni, 2014). Documents facilitate data collection in qualitative studies as they save time and cost by eliminating the need for interviews, observations, or other techniques (Yıldırım \& Şimşek, 2016). In the study, this design was preferred because the study aims to examine analogies in Social Studies textbooks. The data of the study were collected via document analysis technique. The document analysis technique is the process of coding and examining the documents related to the research subject according to a certain system (Çepni, 2014). The document analysis technique allows making inferences about the general trend by examining the available resources in the field. Presenting the general trend in the existing resources may provide an opportunity to reveal the deficiencies and needs in the field, present alternative and different ideas, and enable them to be integrated (Çepni, 2014). Documents are a technique that enables to study of the data needed in qualitative studies by saving time and cost without the need for interviews, observations, or other techniques (Yıldırım \& Şimşek, 2016). The documents constituting the data source of the study are grade 4, 5, 6, and 7 Social Studies textbooks in the 2020-2021 academic year.

\section{Documents Analyzed}

Social Studies textbooks at four different levels, 4th, 5th, 6th and 7th grades, were examined in the research. While the 4th and 5th-grade textbooks were published by private publishing 
houses and each had 208 pages, the 6th-grade textbook had 276 pages, and the 7th-grade textbook had 240 pages and was published by the Ministry of National Education.

Table 1. Social Studies textbooks analyzed

\begin{tabular}{cccccc}
\hline $\begin{array}{c}\text { Textbook } \\
\text { Number }\end{array}$ & Grade & Publisher & $\begin{array}{c}\text { Authors and Publication } \\
\text { Year }\end{array}$ & $\begin{array}{c}\text { Volume } \\
\text { Number }\end{array}$ & $\begin{array}{c}\text { Page } \\
\text { Number }\end{array}$ \\
\hline TB1 & 4 & Tuna & Tüysüz, 2019 & 1 & 208 \\
\hline TB2 & 5 & Anadol & Şahin, 2019 & 1 & 208 \\
\hline TB3 & 6 & MNE & Y1ldırım, Kaplan, Kuru \& & 1 & 276 \\
& & & Yılmaz, 2019 & & \\
\hline TB4 & 7 & MNE & $\begin{array}{c}\text { Açıl, Güvenç, Hayta \& } \\
\text { Kilıç, 2019 }\end{array}$ & \\
& & & & & \\
\hline
\end{tabular}

\section{Data Collection Process}

The data collection process of the study was started after the approval of the ethics committee. The Social and Human Sciences Scientific Research and Publication Ethics Committee of Trabzon University examined the research proposals and deemed them ethically appropriate with the decision numbered "81614018-000-E.405" dated 13.10.2020.

\section{Data Analysis}

This study used content analysis to detect analogies in Social Studies textbooks, while descriptive analysis was used to classify analogies according to their types and learning areas. Descriptive analysis can be expressed as portraying and defining a subject or situation as it is (Ekiz, 2017). In the descriptive analysis, pre-existing codes are used, and it is a preferred analysis type in studies where the conceptual structure of the research is known (Çepni, 2014).

The analogies identified in the textbooks used at different grade levels in the study were examined in terms of quantity and quality, included in the analogic classification, and coded separately by each researcher. In the grouping of analogies in the examined textbooks, the analogy categories in the studies of Curtis and Reigeluth (1984), Thiele and Treagust (1991), and Şahin (2010) were taken as a basis. In the study, four textbooks published by the Ministry of National Education and private publishing houses were examined as documents. The textbooks were first read independently by the researchers, and the identified analogies were independently coded and classified by the researchers. Afterward, the researchers 
compared the analogies and classifications that they coded independently, and agreed-upon codes were tabulated. For example, while the analogies on page 148 of the 5th grade Social Studies textbook were evaluated as separate analogies by two researchers, they were accepted as one analogy by one researcher. In this case, by exchanging ideas for the analogies in question, it was decided that each statement should be accepted as a different analogy. Approximately seven months later, the researchers came together again and recorded the analogies they had determined before. The researchers compared the codes they created before and after, thus ensuring both the internal reliability, namely, the consistency, and the external validity, namely, repeatability, of the study (Yıldırım \& Şimşek, 2016). An example of the analysis and coding of analogies is given in Figure 2.

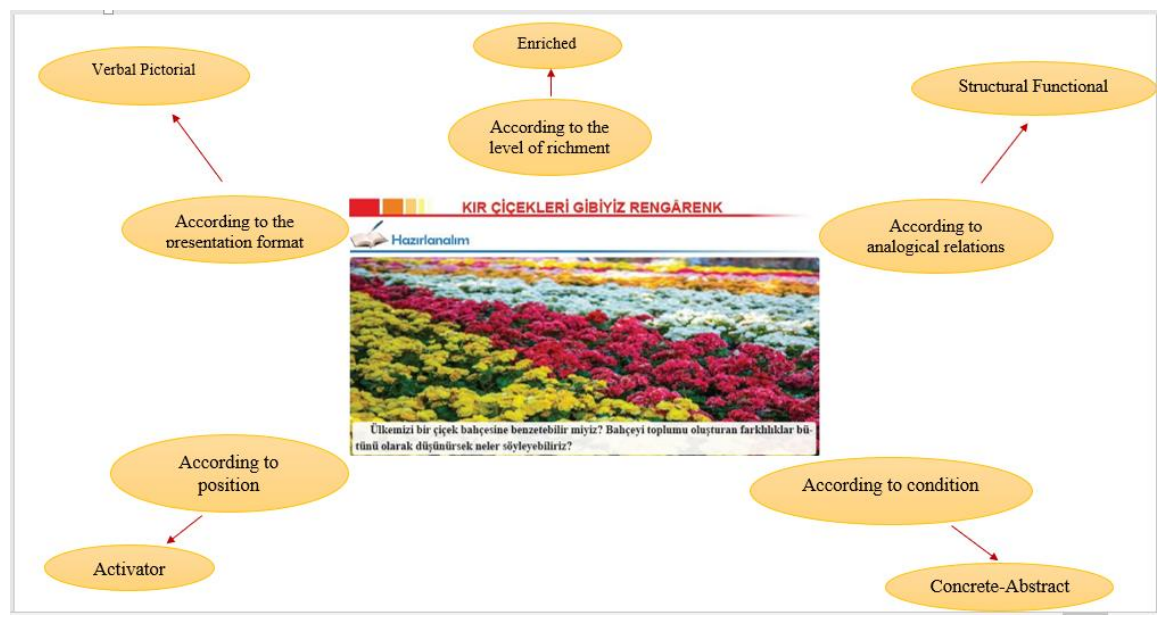

Figure 2. Example of analogy analysis from 6th grade Social Studies textbook

The agreed-upon data were digitized and presented in tables as suggested by Çepni (2014). In this context, the use of analogies in Social Studies textbooks at different grade levels, their distribution according to learning areas, and the findings of their types are presented in tables. Information describing each table is given below the relevant table. By using the codes indicating the grade level and page number in the table and text, the confirmability of the data from the textbook was ensured. For example, the code SB5-78 refers to page 78 of the Social Studies 5th grade textbook. In addition, columns were created for the relevant grade level in some tables, and it was possible to check the analogy from the relevant textbook using the page number. For example, in Table 4, there are two analogies in the field of Science and Society learning at the 4th-grade level. When classifying these two analogies, it is presented with the page and line numbers. In addition, the frequency information of the analogies used in the learning area of the grade level related to the total expression is included Ayrıca toplam ifadesiyle ilgili sınıf düzeyinin öğrenme alanında 
kullanılan analojilerin frekans bilgisine yer verilmiştir. If more than one analogy is found on the same page, letters such as "a-b-c", each representing an analogy, are assigned to each analogy. For example, the SB7-177a code represents an analogy found on page 177 of the 7th grade Social Studies textbook, while the SB6-148abcd code represents four analogies of the same type found on page 148 of the 6th grade Social Studies textbook.

\section{Findings}

In this section, in accordance with the problem statement of the research, the use of analogies in the 4-7th grade Social Studies textbooks and their distribution according to the analogy classification, grade levels, and learning areas are presented in tables.

\section{Findings on the First Sub-Problem}

Within the scope of the first sub-problem of the research, the distribution of analogies used in 4th, 5th, 6th, and 7th Grade Social Studies textbooks according to analogy types and grade levels was examined, and the data obtained are presented in Table 2 and Table 3.

Table 2. Analogies used in social studies textbooks and their distribution by analogical classification

\begin{tabular}{|c|c|c|c|}
\hline Analogies & & Frequency & Page \\
\hline \multirow{3}{*}{ By Their Relations } & Structural & 6 & $\begin{array}{l}\text { SB4-25, SB4-47, } \\
\text { SB4-48, SB4-64, } \\
\text { SB5-47, SB7-133 }\end{array}$ \\
\hline & Functional & 15 & $\begin{array}{c}\text { SB4-21, SB4-169, } \\
\text { SB5-65, SB6-107, } \\
\text { SB6-237, SB7-18, } \\
\text { SB7-83, SB7-136, } \\
\text { SB7-159, SB7-163, } \\
\text { SB7-165, SB7-173, } \\
\text { SB7-177(a), SB7- } \\
\text { 177(b), SB7-215 }\end{array}$ \\
\hline & $\begin{array}{l}\text { Structural - } \\
\text { Functional }\end{array}$ & 3 & $\begin{array}{c}\text { SB5-46, SB6-27, } \\
\text { SB6-32 }\end{array}$ \\
\hline By Presentation Format & Verbal & 22 & $\begin{array}{l}\text { SB4-21, SB4-25, } \\
\text { SB4-47, SB4-48, }\end{array}$ \\
\hline
\end{tabular}


SB4-64, SB4-169,

SB5-46, SB5-47,

SB5-65, SB6-27,

SB6-107, SB6-

237, SB7-18,

SB7-83, SB7-136,

SB7-159, SB7-

163, SB7-165,

SB7-173, SB7-

177(a), SB7-

177(b), SB7-215

\begin{tabular}{lll}
\hline Pictorial & - & \\
\hline Verbal - & 2 & SB6-32, SB7-133 \\
Pictorial & &
\end{tabular}

SB4-25, SB4-47,

SB4-64, SB5-46,

SB5-47, SB5-65,

Concrete -

SB6-107, SB6-237,

Concrete

16

SB7-18, SB7-83,

SB7-133, SB7-159,

By Concreteness vs.

SB7-163, SB7-165,

Abstractness

SB7-173, SB7-

177(b)

Abstract -

Abstract

SB4-21, SB4-48,

SB4-169, SB6-27,

Concrete -

8

SB6-32, SB7-136,

Abstract

SB7-177(a), SB7-

215

SB4-25, SB4-47,

By Their Functions

Advance

Organizer

SB6-27, SB6-107,

SB6-237, SB7-133, 
SB7-159, SB7-165,

SB7-215

SB4-21, SB4-64,

SB4-169, SB5-46,

SB5-47, SB5-65,

Activator

13

SB6-32, SB7-18,

SB7-83, SB7-136,

SB7-163, SB7-

177(a), SB7-177(b)

$\begin{array}{ccc}\text { Post-Organizer } & 2 & \text { SB4-48, SB7-173 } \\ & \text { SB4-47, SB4-48, } \\ & \text { SB4-64, SB4-169, } \\ & \text { SB5-47, SB5-65, } \\ \text { Simple } & & \text { SB6-107, SB7-18, } \\ & & \text { SB7-83, SB7-136, } \\ & & \text { SB7-159, SB7-173, }\end{array}$

SB7-177(a)

Bythe Level Of Richness

SB4-25, SB6-27,

SB6-237, SB7-

Enriched

8

133, SB7-163,

SB7-165, SB7-

177(b), SB7-215

\begin{tabular}{lll}
\hline Extended & 3 & SB4-21, SB5-46,
\end{tabular}

SB6-32

Total

24

SB4-190, SB5-42,148(a-

b-c-d), SB6-139(a-b-c-

Personal Analogies

20

d),202, SB7-

$29,146,147,151,162,170$,

$181,184,212$ 
As seen in Table 2, 44 analogies, 24 of which can be classified according to presentation format, status, and task, and 20 of which are personal, were identified in the 4th, 5th, 6th, and 7th grades Social Studies textbooks. While there are no pictorial and abstract-abstract analogies according to the presentation format in the course books, it has been determined that at least one analogy type is included in all the course books. Types of analogies that are rarely included in the textbooks are verbal - pictorial (2) analogies in terms of presentation format, post-organizer analogies in terms of function (2), structuralfunctional analogies in terms of relationships, and (3) expanded in terms of richness level (3). It was determined that the most common analogies are verbal analogies in terms of presentation format, concrete-concrete analogies in terms of the level of concreteness, and personal analogies.

As can be seen in Table 3, 4 structural and two functional analogies are included in the 4th-grade textbook according to their relationships, while structural-functional analogies are not included at all. While six verbal analogies were included in the 4th-grade textbook, verbal pictorial and pictorial analogies were never used. While three concrete-concrete and three concrete-abstract analogies are included in the 4th-grade textbook, the abstract-abstract analogy type is not included at all. In terms of function, two advance organizers, three activators, and one final organizer analogy are included, while four simple, one expanded, and one enriched analogy are included according to the level of richness. One personal analogy is included in the 4th-grade textbook. A total of 7 analogies were identified in the 4th grade Social Studies textbook. While structural, verbal, and simple analogies are mainly included in the textbook, structural-functional, pictorial, verbal-pictorial, and abstractabstract analogies are not included at all.

According to Table 3, 1 structural, one functional, and one structural-functional analogy type are included in the 5th-grade textbook according to their relationships. While three verbal analogies were included in the 5th-grade textbook, pictorial and verbal analogies were never used. Likewise, while 3 concrete-concrete analogies are included in the 5th-grade textbook, concrete-abstract and abstract-abstract analogies are not included at all., While there were 3 activating analogies were included, there were no advance-organizer and post-organizer analogies at all. While 2 simple analogies were included according to the level of richness, enriched and expanded analogy types were not included at all. 5 personal analogies were included in the 5th-grade textbook. A total of 8 analogies were identified in the 5 th grade Social Studies textbook. While 5 analogies are mainly included in the personal 
analogy type in the textbook, pictorial, verbal-pictorial, abstract-abstract, concrete-abstract, advance-organizing, post-organizing, and enriched analogies are not included at all.

Table 3. Distribution of analogy types in social studies textbooks by grade levels

\begin{tabular}{|c|c|c|c|c|c|c|}
\hline Analogic & & th Grade & $5^{\text {th }}$ Grade & ; th Grade $^{\text {th }}$ & $7^{\text {th }}$ Grade & Total \\
\hline \multirow{3}{*}{ By Their Relations } & Structural & 4 & 1 & - & 1 & 6 \\
\hline & Functional & 2 & 1 & 2 & 10 & 15 \\
\hline & $\begin{array}{l}\text { Structural - } \\
\text { Functional }\end{array}$ & - & 1 & 2 & - & 3 \\
\hline \multirow{3}{*}{ Bypresentation Format } & Verbal & 6 & 3 & 3 & 10 & 22 \\
\hline & Pictorial & - & - & - & - & - \\
\hline & $\begin{array}{l}\text { Verbal - } \\
\text { Pictorial }\end{array}$ & - & - & 1 & 1 & 2 \\
\hline \multirow{3}{*}{$\begin{array}{l}\text { 3Y CONCRETNESS } \\
\text { Is ABSTRACTNESS } \\
\text { LEVEL }\end{array}$} & $\begin{array}{l}\text { Concrete - } \\
\text { Concrete }\end{array}$ & 3 & 3 & 2 & 8 & 16 \\
\hline & $\begin{array}{l}\text { Abstract - } \\
\text { Abstract }\end{array}$ & - & - & - & - & - \\
\hline & $\begin{array}{l}\text { Concrete - } \\
\text { Abstract }\end{array}$ & 3 & - & 2 & 3 & 8 \\
\hline \multirow{3}{*}{ By Function } & $\begin{array}{l}\text { Advance- } \\
\text { Organizer }\end{array}$ & 2 & - & 3 & 4 & 9 \\
\hline & Activator & 3 & 3 & 1 & 6 & 13 \\
\hline & Post-Organizer & 1 & - & - & 1 & 2 \\
\hline \multirow{3}{*}{$\begin{array}{l}\text { By Level Of } \\
\text { Richness }\end{array}$} & Simple & 4 & 2 & 1 & 6 & 13 \\
\hline & Enriched & 1 & - & 2 & 5 & 8 \\
\hline & Expanded & 1 & 1 & 1 & - & 3 \\
\hline Personal Analogies & & 1 & 5 & 5 & 9 & 20 \\
\hline Total & & 7 & 8 & 9 & 20 & 44 \\
\hline
\end{tabular}

As can be seen in Table 3, while 2 functional and 2 structural functional analogies were included in the 6th-grade textbook according to their relations, the structural analogy type was not included at all. While 3 verbal and 3 verbal pictorial analogies were used according to the presentation format, pictorial analogies were never used. While 2 concreteconcrete analogies and 2 concrete-abstract analogies are included in the 6th-grade textbook 
depending on the situation, the abstract-abstract analogy type is not included at all. According to its task, 3 pre-organizing and 1 activating analogy were included, while post organizing analogy was not included at all. According to the level of richness, 1 simple, 1 expanded, and 2 enriched analogies are included. 5 personal analogies are included in the 6th-grade textbook. A total of 9 analogies were identified in the 6th grade Social Studies textbook. While the textbook mainly includes personal analogy, structural, pictorial, and abstract-abstract analogies are not included at all.

As can be seen in Table 3, 1 structural and 10 functional analogies were included in the 7th-grade textbook according to their relationships, while the structural-functional analogy type was not included at all. According to the presentation format, 10 verbal and 1 verbal pictorial analogy were included, while pictorial analogies were never used. While 8 concrete-concrete and 3 concrete-abstract analogies are included in the 7th-grade textbook, abstract-abstract analogies are not included at all. According to its function, 4 preorganizers, 6 activators, and 1 post-organizer analogy are included. While 6 simple and 5 enriched analogies were determined according to the richness level, no expanded analogy was included at all. 9 personal analogies are included in the 7th grade Social Studies textbook. A total of 20 analogies were identified in the 7th grade Social Studies textbooks. While most of the time functional and verbal analogies are included in the textbook, structural-functional, pictorial, abstract-abstract, and expanded analogies are not included at all. It has been determined that the use of analogy is more prominent in the 7th grade Social Studies textbook compared with the other textbooks examined.

\section{Findings on the second sub-problem}

In line with the second sub-problem of the research, the distribution of analogies in the 4th7th grade Social Studies textbook according to learning areas and their classification according to analogy types were examined. In this framework, the distribution of analogy types in the 4th-7th grade Social Studies textbook and the distribution of analogies in learning areas is presented in Table 4. 
Table 4. Classification of analogies in social studies textbooks according to learning areas and analogy types

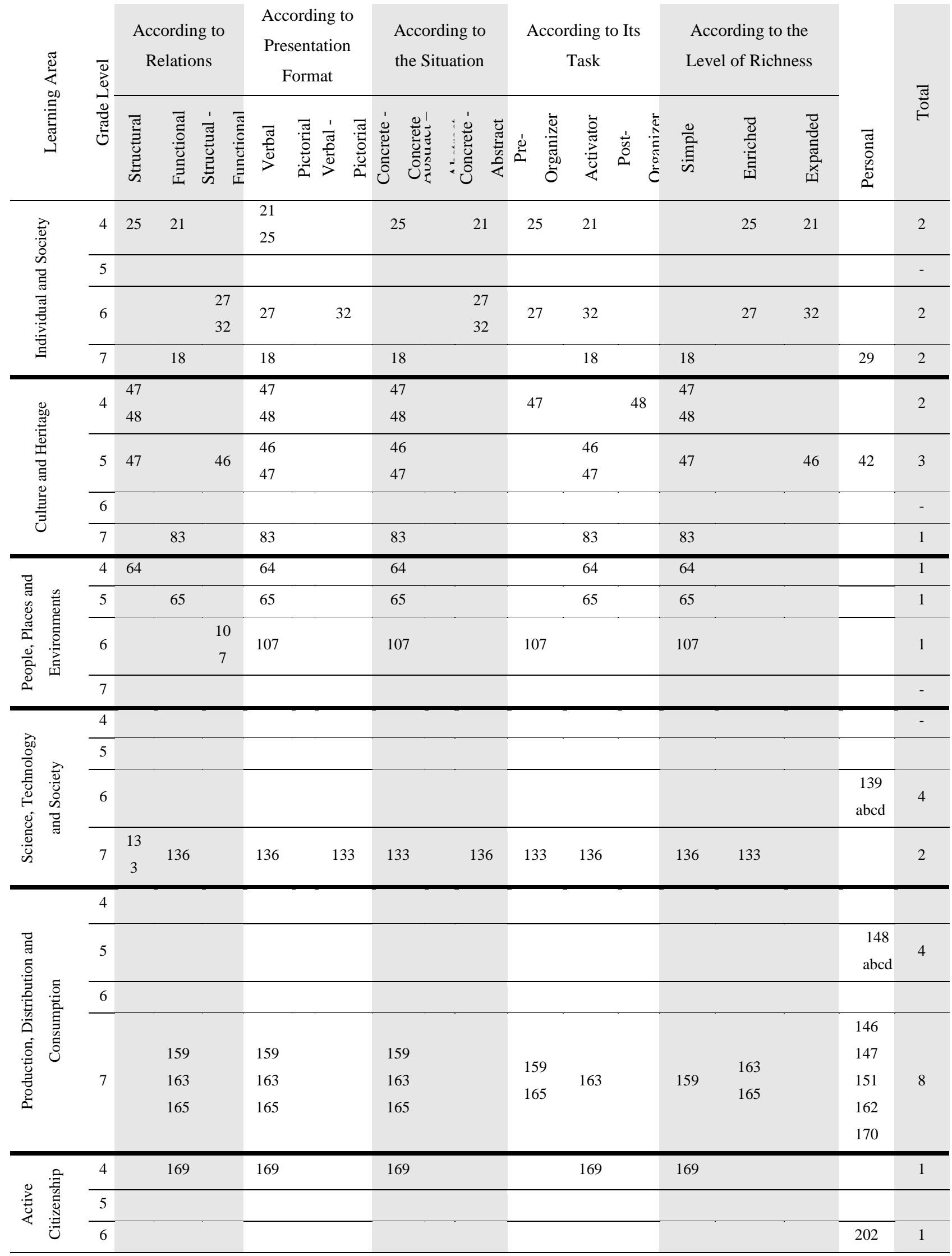




\begin{tabular}{|c|c|c|c|c|c|c|c|c|c|c|c|c|}
\hline & 7 & $\begin{array}{c}173 \\
177 \\
a b\end{array}$ & $\begin{array}{c}173 \\
177 \\
\mathrm{ab}\end{array}$ & $\begin{array}{c}173 \\
177 b\end{array}$ & $177 \mathrm{a}$ & & $\begin{array}{c}177 \mathrm{a} \\
\mathrm{b}\end{array}$ & $\begin{array}{c}17 \\
3\end{array}$ & $\begin{array}{c}173 \\
177 \mathrm{a}\end{array}$ & $177 \mathrm{~b}$ & $\begin{array}{l}181 \\
184\end{array}$ & 5 \\
\hline \multirow{4}{*}{ 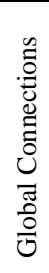 } & 4 & & & & & & & & & & 190 & 1 \\
\hline & 5 & & & & & & & & & & & - \\
\hline & 6 & 237 & 237 & 237 & & 237 & & & & 237 & & 1 \\
\hline & 7 & 215 & 215 & & 215 & 215 & & & & 215 & 212 & 2 \\
\hline
\end{tabular}

When distribution of a total of 7 analogies identified in the 4th grade Social Studies textbook across learning areas are examined, it is seen that in the "Individual and Society" learning area, there are one functional, one structural, two verbal, one concrete-concrete, one concrete-abstract, one activator, one pre-organizer, one enriched and expanded analogy. In the "Culture and Heritage" learning area of the 4th grade Social Studies textbook, types of analogies used are: two functional, two verbal, two concrete-concrete, one pre-organizer, one post-organizer, and two simple. In the learning area of "People, Places, and Environments", only one analogy from each type of analogy was used: one structural, one verbal, one concrete-concrete, one activator, and one simple. When the "Active Citizenship" learning area was examined, it was seen that one analogy was used, one functional, one verbal, one concrete-concrete activator, and one simple. "Etkin Vatandaşlık" öğrenme alanı incelendiğinde bir fonksiyonel, bir sözel, bir somut-somut bir aktifleştirici, bir basit olmak üzere 1 analoji kullanıldığı görülmüştür. While a personal analogy was included in the "Global Connections" learning area, which is another learning area, no analogy could be detected in the learning areas of "Science, Technology and Society" and "Production, Distribution, and Consumption" (Table 4). In this case, analogies are mostly found in the first two learning areas: "Individual and Society" and "Culture and Heritage". On the other hand, there is no analogy in the learning areas of "Science, Technology and Society" and "Production, Distribution, and Consumption".

When the distribution of eight analogies determined in the 5th grade Social Studies textbook across learning areas was examined, it was observed that, 1 structural, 1 structuralfunctional, 2 verbal, 2 concrete-concrete, 2 activating, and 3 analogies as 1 simple, 1 expanded, 1 personal, are used in the "Culture and Heritage" learning area. In learning area of "People, Places, and Environments", 1 functional, 1 verbal, 1 concrete-concrete, 1 activator, and 1 simple analogy were used. There are 4 personal analogies in the 
"Production, Distribution and Consumption" learning area and 1 personal analogy in the "Global Connections" learning area. In this case, the use of analogy in the learning field of "Production, Distribution and Consumption" was prioritized. On the other hand, no analogy could be found in the learning areas of "Individual and Society", "Science, Technology and Society", "Active Citizenship" and "Global Connections".

$\mathrm{T}$ When the distribution of 9 analogies in the 6th grade Social Studies textbook to learning areas was examined, it was seen that, 2 structural-functional, 1 verbal, 1 verbalpictorial, 2 concrete-abstract, 1 activator, 1 pre-organizer, 1 enriched and 1 expanded in the learning area of "Individual and Society" . In the learning area of "People, Places and Environments", one analogy was used the types of structural-functional, verbal, concreteconcrete, pre-organizing and simple type. "İnsanlar, Yerler ve Çevreler" öğrenme alanında yapısal-fonksiyonel, sözel, somut-somut, ön organize edici ve basit türde olmak üzere 1 analoji kullanılmıştır. There are 4 personal analogies in the "Science, Technology and Society" learning area, and 1 personal analogy in the "Active Citizenship" learning area, which is another learning area. Similarly, in the "Global Connections" learning area, analogies were used as one analogy from each type of functional, verbal, concrete-concrete, advance-organizing and enriched analogies. In this case, while the most intense analogy is found in the learning area of "Science, Technology and Society", it has been determined that there is no analogy in the learning areas of "Culture and Heritage" and "Production, Distribution and Consumption".

When we considered the distribution of 20 analogies identified in the 7 th grade Social Studies textbook to learning areas, it was seen that types of analogies used in the "Individual and Society" learning area are : 1 functional, 1 verbal, 1 concrete-concrete, 1 activator, 1 simple and 1 personal. In the learning area of "Culture and Heritage", one analogy was used from each type of functional, verbal, concrete-concrete, activating and simple analogy. In another learning area of "Science, Technology and Society", analogies used are as follows: 1 structural, 1 functional, 1 verbal, 1 verbal-picture, 1 concrete-concrete, 1 concrete-abstract, 1 activator, 1 pre-organizer, 1 simple and 1 enriched. In the "Production, Distribution and Consumption" learning area, analogies were distributed across different types in the following way:, 3 functional, 3 verbal, 3 concrete-concrete, 2 advanceorganizer, 1 activator, 1 simple, 2 enriched and 5 personal. It has been determined that there were 5 analogies, 3 functional, 3 verbal, 2 concrete-concrete, 1 concrete-abstract, 2 activator, 1 post-organizer, 2 simple, 1 enriched and 2 personal are included in the "Active 
Citizenship" learning area. In the "Global Connections" learning area, types of analogies used are: included, 1 functional, 1 verbal, 1 concrete-abstract, 1 advance organizer, 1 enriched and 1 personal. In this case, it has been determined that there is no analogy in the learning field of "People, Places and Environments" learning area, while the analogies are extensively found in the "Production, Distribution and Consumption" learning area. When the 7th grade Social Studies textbook is compared with the other textbooks examined, it has been determined that the use of analogy is more prominent.

Within the scope of the second sub-problem of the research, analogies in grade 4, 5, 6 and 7 Social Studies textbooks were compared in terms of learning areas. The findings obtained as a result of this comparison are as follows:

- While two analogies were detected in the 4th and 7th grades in the "Individual and Society" learning area, no analogies were detected in the 5th grade level in the same learning area.

- While 2 analogies were detected in the 4th Grade, 3 in the 5th Grade and 1 in the 7th Grade in the "Culture and Heritage" learning area, no analogy could be detected in the 6th grade textbook in the same learning area.

- While one analogy was detected in grade 4, 5, and6 grades in the "People, Places and Environments" learning area, no analogy could be found in the 7th grade textbook in the same learning area.

- While 4 analogies were detected in the 6th Grade and 2 in the 7th Grade in the "Science, Technology and Society" learning area, no analogies were detected at the 4th and 5th grade levels in the same learning area.

- While there were 4 analogies in the 5th Grade and 8 analogies in the 7th Grade in the "Production, Distribution and Consumption" learning area, no analogies were found in the 4th and 6th grade textbooks.

- While one analogy was found in each of grade 4 and 6 textbook and five in grade 7 textbook in the "Active Citizenship" learning area, no analogy could be found in the 5th grade textbook in the same learning area.

- While one analogy was detected in each of the 4th and 6th grade textbooks in the "Global Connections" learning area, and two analogies were detected in the 7th grade textbook, no analogies were found in the 5th grade textbooks in the same learning area. 


\section{Discussion and Conclusion}

As a result of the research, it was seen that a total of 44 analogies were used in 7 learning areas. Seven of them were in the 4th grade Social Studies textbook, 8 in the 5th Grade, 9 in the 6th Grade, and 20 in the 7th Grade (Table 3). In general, it can be said that analogies are rarely included in Social Studies textbooks. In addition to this result, in general, it was observed that the limitations were not specified in the analogies used. In other words, the richness levels of the analogies were found to be weak. This result complies with some studies in the literature. Kaya (2010), in her master's thesis, examined 16 Science and Technology textbooks between the 4th and 8th grades and concluded that the limitations of analogies in the textbooks were not adequately addressed. In his study, Newton (2003) examined 35 primary school science textbooks and identified 92 analogies, most of which were of simple type. In their study, Orgill and Bodner (2006) examined eight biochemistry textbooks at the university level and concluded that the number of analogies in the books in which the limitations were explained was insufficient. In their study, Thiele and Treagust (1991) examined 8 Chemistry books, identified a total of 70 analogies, and concluded that most of these analogies were of simple type. Demirci, Güler, and Yağbasan (2008) examined the 4th, 5th, and 6th Grade Science and Technology and 7th and 8th Grade Science textbooks and concluded that a significant rate of the 89 analogies identified was of simple type.

Another result reached in the study is that analogies used in Social Studies textbooks are not homogeneously distributed in the learning areas. No analogies were found in some learning areas in the textbooks at different grade levels. On the other hand, analogies used in textbooks concentrate on some of the learning areas. These results led to the idea that analogies in textbooks were not used consciously and systematically.

When the textbooks are considered according to the grade level, it has been determined that the use of analogy increases as the grade level increases, and the use of analogy in the textbooks is found to be insufficient. However, it can be stated that analogies gain more intensity in the 7th-grade textbook compared to the other textbooks examined. This situation led to the opinion that the 7 th-grade textbook writers paid more attention to the use of analogy. In addition, it can be said that there are more analogies in the textbooks published by the Ministry of National Education compared to the private publishing houses. This situation can be explained by the fact that the number of pages of the textbooks published by the Ministry of National Education is higher than that of the private publishing 
houses. This can be attributed to the fact that the authors of textbooks published by the MNE better realized the affordances of using analogies extensively.

It is important to let students know the source in analogies (Harrison \& Treagust, 1993; Orgill \& Bodner, 2004; Treagust et al., 1994). In cases where the students do not know the source, the analogy cannot achieve its purpose, and this may cause misconceptions in the students who cannot establish the target-source relationship (Cho, Kahle, \& Norland 1985; Dikmenli \& Çardak, 2004; Gündüz, Yılmaz, Çimen \& Şen, 2017; Harrison \& Treagust, 1993; Heywood and Parker, 1997; Kete, 2006). The visuals used to concretize the subject in the examined textbooks were designed only for the promotion of the target, and the image of the source was not added to the figure (Picture-1). This situation has caused analogies that have the potential to be pictorial analogies to be categorized only as verbal analogies.

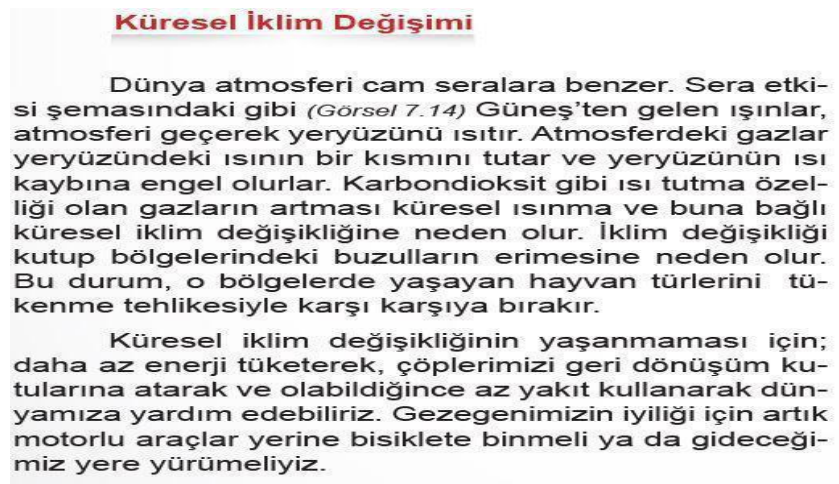
atmosferi geçerek yeryüzünü isıtır. Atmosferdeki gazlar yeryüzündeki ısının bir kısmını tutar ve yeryüzünün ısı kaybına engel olurlar. Karbondioksit gibi isı tutma özelliği olan gazların artması küresel ısınma ve buna bağlı küresel iklim değişikliğine neden olur. İklim değişikliği kutup bolgelerindeki buzulların erimesine neden olur. Bu durum, o bölgelerde yaşayan hayvan türlerini tükenme tehlikesiyle karşı karşıya bırakır.

Küresel iklim değişikliğinin yaşanmaması için; daha az enerji tüketerek, çöplerimizi geri dönüșüm kutularına atarak ve olabildiğince az yakıt kullanarak dünyamıza yardım edebiliriz. Gezegenimizin iyiliği için artık motorlu araçlar yerine bisiklete binmeli ya da gideceğimiz yere yürümeliyiz.

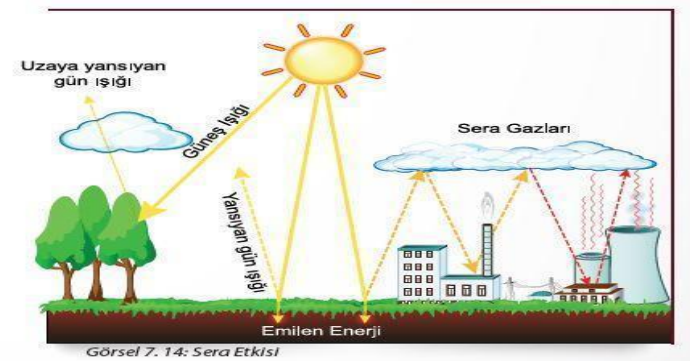

Picture 1. SB7-215

The fact that the analogies used in the textbooks are mostly personal analogies requires students to imagine themselves in an imagery situation. It is thought that this situation will develop the imagination of students. In addition, the main purpose of the use of analogies is to enable abstract and complex situations to be understood with concrete and understandable examples (Akkuzu \& Akcay, 2011; Heywood, 2002). In this sense, the fact that different types of analogies that can help connect examples and concretize abstract information are given an inadequate place in the textbooks has led to the idea that teachers should eliminate the inadequacies.

When the studies on textbooks, in general, are examined, it is striking that the number of studies that found textbooks educationally positive is limited (Demirci, 2007; Inal \& Mentiş Taş, 2011). Although studies in the literature find the textbooks partially positive and partially negative (Güven, 2010), the opinion that the textbooks are educationally 
inadequate in general prevails. In most of the studies on textbooks in the literature, it is emphasized that textbooks are insufficient in terms of presenting educational elements and are not suitable for the constructivist approach (Türk \& Dursun, 2006; Gülcan, 2007; Çalışkan, 2006). In addition, it was concluded that the textbooks are lacking in activities that can help students construct concepts, and some expressions may cause misconceptions (Karadüz, 2006; Özay \& Hasenekoğlu, 2006). In this context, in parallel with the literature, it can be stated that analogies in Social Studies textbooks are not considered educationally sufficient due to their simple and inadequate use.

This study is limited to the 4th, 5th, 6th, and 7th grade Social Studies textbooks, which were examined within the scope of the research and approved by the Board of Education in the 2020-2021 academic year for use in classes. It is thought that this study, which examines analogies in Social Studies textbooks in terms of quantity and quality, provides an opportunity to offer suggestions for increasing the use of analogies in textbooks and enriching their quality.

\section{Suggestions}

In line with these results, the following recommendations can be made:

- It has been determined that analogies are rarely included in Social Studies textbooks. The number of analogies used in textbooks can be increased to facilitate concretization and learning.

- Various training opportunities can be offered to pre-service and in-service teachers so that they can better recognize and correct mentioned inadequacies.

- It has been determined that analogies are not used homogeneously and in a balanced way in Social Studies textbooks; they are piled up in some learning areas, and they are not used at all in some others. Analogies can be used in a balanced and homogeneous way on the basis of learning areas.

- Most of the analogies in Social Studies textbooks are personal and at a simple level. By increasing the richness level of these analogies, their qualities can be improved.

- In the analogies used in Social Studies textbooks, the relationship between the source and the target is mostly given at the basic level. In order to make analogies more effective, limitations and dissimilar aspects of the relationship between source and target can also be highlighted. 
- It was found that visuals weakly supported the analogies in the Social Studies textbooks, and it was determined that they were designed only to promote the target. In analogies, it is recommended to use pictures for both parties to make the relationship between the target and the source more understandable. For this reason, analogies can be supported with visuals depending on their presentation format. In addition, studies can be conducted to check whether verbal analogies are understood correctly.

Ethical Approval: This research was conducted with the permission of the Trabzon University Social and Human Sciences Research and Ethics Committee, with the decision dated 13/10/2020 and numbered 81614018-000-E.405.

Conflict Interest: There was no conflict of interest among the authors in this study.

Authors Contributions: The authors contributed equally to the study.

\section{References}

Adnan, Y. A. (2015). Ortaöğretim 12. sınıf biyoloji ders kitabında kullanılan analojiler üzerine bir araştırma. (Yüksek lisans tezi). Yükseköğretim Kurulu Ulusal Tez Merkezi'nden edinilmiştir. (Tez No. 407549).

Akkuzu, N. \& Akcay, H. (2011). An effective model to increase student attitude and Achievement: Narrative including analogies. US-China Education Review, 5, $612-$ 623.

Akman, Ö. \& Bastık, U. (2016). Sosyal bilgiler ders kitaplarında ihtilaflı konular içerisinde yer alan "aile" 'kavramının incelenmesi: bir içerik analizi. Trakya Üniversitesi Ĕgitim Fakültesi Dergisi, 6(2).

Atav, E., Erdem, E., Yılmaz, A. \& Gücüm, B. (2004). Enzimler konusunun anlamlı öğrenilmesinde analojiler oluşturmanın etkisi. Hacettepe Üniversitesi Ĕ̆itim Fakültesi Dergisi, (27), 21-29.

Aydemir, M. (2017). Ortaokul sosyal bilgiler ders kitaplarının ortaokul sosyal bilgiler dersi öğretim programında yer alan beceriler açısından incelenmesi. Uluslararası Güncel Eğitim Araştırmaları Dergisi, 3(2), 1-17. 
Azizoğlu, N., Çamurcu, M. \& Kırtak-Ad, V. N. (2014). Ortaöğretim fizik ders kitaplarında analojilerin kullanımı: Belirleme ve sınıflandırma çalışması. Journal of Turkish Science Education, 11(2), 36-59.

Barton, K. \& Smith, L. (2000). Themes or motifs? Aiming for coherence through interdisciplinary outline. The Reading Teacher, 54, (1), 54-63.

Baş, K. (2020). Sosyal bilgiler ders kitaplarında sanat kavramının ve sanat içerikli konuların yeri. Akdeniz Ĕ̆itim Araştırmaları Dergisi, 14(31), 668-691.

Bayazit, İ. (2011). Öğretmen adaylarının matematik öğretiminde analoji kullanımları konusundaki görüş ve yeterlilikleri. Selçuk Üniversitesi Ahmet Keleşoğlu Ĕğitim Fakültesi Dergisi, (31), 139-158.

Ceyhan, E. \& Yiğit, B. (2005). Konu alanı ders kitabı incelemesi. Ankara: Anı Yayıncılık.

Cho, H.H., Kahle, J.B. \& Norland, F.H. (1985). An 1nvestigation of high school biology textbooks as sources of misconceptions and difficulties in genetics and some suggestions for teaching genetics. Science Education, 69(5), 707-719.

Curtis, R. V. \& Reigeluth, C. M. (1984). The use of analogies in written text. Instructional Science, (13), 99-117.

Çalışkan, N. (2006). Türkiye'deki ortaöğretim edebiyat ders kitapları üzerine edebiyat eğitimi açısından bir değerlendirme. Milli Eğitim Dergisi, 34 (169), 355-364.

Çeken, R. (2011). İlköğretim fen ve teknoloji ders kitaplarında kalp ve akciğer ile ilgili şekillerin analizi. Kastamonu Eğitim Dergisi, 19 (3), 903-912.

Çepni, S. (2014). Araştırma ve proje çalışmalarına giriş. Trabzon: Celepler Matbaacılık.

Çıray, F. (2010). Illkögrretim disiplinler arası analoji tabanlı öğretimin ögrencilerin öğrenme düzeylerine etkisi. (Yayınlanmamış yüksek lisans tezi). Anadolu Üniversitesi Eğitim Bilimleri Enstitüsü, Eskişehir.

Demir, S., Önen, F. \& Şahin, F. (2011). Fen bilgisi öğretmen adaylarının bakış açısıyla analojiler. Necatibey Eğitim Fakültesi Elektronik Fen ve Matematik Ĕ̈itimi Dergisi, 5 (2), 86-114.

Demir, Y. \& Atasoy, E. (2018). 5. sınıf sosyal bilgiler ders kitabının (2017) değerlendirilmesi. Uludă̆ Üniversitesi Eğitim Fakültesi Dergisi, 31(2), 753-780. 
Demirci Güler, M. P. (2007). Fen öğretiminde kullanılan analojiler, analoji kullanımının ögrenci başarısı, tutumu ve bilginin kalıcılı̆̆ına etkisinin araştırllması. (Doktora tezi) Yükseköğretim Kurulu Ulusal Tez Merkezi’nden edinilmiştir. (Tez No. 211828).

Demirci Güler, P. \& Yağbasan, R. (2008). Fen ve Teknoloji ders kitaplarında kullanılan analojilerin ve analojilere ilişkin sorunların betimlenmesi. İn̈nü Üniversitesi Eğitim Fakültesi Dergisi, 9(16), 105-122.

Demirci, C. (2007). Fen bilgisi 6, 7 ve 8. sınıf ders kitaplarının değerlendirilmesi. Hacettepe Üniversitesi Eğitim Fakültesi Dergisi, 33, 108-119.

Dikmenli, M. (2015). A study on analogies used in new ninth grade biology textbook. AsiaPacific Forum on Science Learning and Teaching, 16(1), 1-20.

Dikmenli, M. ve Çardak, O. (2004). A Study on misconceptions in the 9th grade high school biology textbooks. Eurasian Journal of Educational Research, (17), 130-141.

Dilber, R. (2006). Fizik ögrretiminde analoji kullanımının ve kavramsal değişim metinlerinin kavram yanılgılarının giderilmesine ve öğrenci başarısına etkisinin araştırılması. (Doktora tezi). Yükseköğretim Kurulu Ulusal Tez Merkezi'nden edinilmişsir. (Tez No. 181511).

Duit, R. (1991). On the role of analogies and metaphors in learning science. Science Education, 75(6), 649-672.

Duman, N. (2016). An Example of the Use of Personal Analogy in Teaching Geography: If I Were a Mineral. Educational Research and Reviews, 11(8), 721-731.

Duman, N., Özgürbüz, İ., \& Şeyihoğlu, A. (2020). Reflections of the teaching-withanalogies model (TWA) on the teaching of geography. OPUS Uluslararası Toplum Araştırmaları Dergisi, 16(29), 1642-1665.

Ekici, E., Ekici, F. ve Aydın, F. (2007). Fen bilgisi derslerinde benzeşimlerin (analoji) kullanılabilirliğine ilişkin öğretmen adaylarının görüşleri ve örnekleri. Ahi Evran Üniversitesi Kırşehir Ĕ̈itim Fakültesi Dergisi, 8 (1), 95-113.

Gedik Demirkaya, H. (2008). Sosyal bilgiler ders kitaplarında güncel konular. Türkiye Sosyal Araştırmalar Dergisi, (1), 117-134. 
Glynn, S. M., \& Takahashi, T. (1998). Learning from analogy-enhanced science text. Journal of Research in Science Teaching, 35(10), 1129-1149.

Gülcan, B. K. (2021). Fen lisesi biyoloji ders kitaplarındaki metaforların, analojilerin ve teleolojilerin incelenmesi. (Yüksek lisans tezi). Yükseköğretim Kurulu Ulusal Tez Merkezi'nden edinilmiştir. (Tez No. 675299).

Gülcan, M. G. (2007). İlköğretim Sosyal Bilgiler 5. sınıf ders kitabı inceleme (görsel ve eğitsel tasarım). Çukurova Üniversitesi Eğitim Fakültesi 3. Sosyal Bilimler Eğitimi Kongresi, 305-311.

Gülersoy, A. E. (2012). İdeal ders kitabıi arayıişıinda sosyal bilgiler ders kitaplarıinıin bazii özellikler açiisindan incelenmesi. International Journal of New Trends in Arts, Sports \& Science Education, 2(1), 8-26.

Gürkan, B. \& Doğanay, A. (2016). Sosyal bilgiler dersinde disiplinler arası öğretim yaklaşımına dayalı analoji tekniği uygulamalarının kavram gelişimine etkisi: bir durum çalışması, Turkish Studies, 11(16), 395-416.

Güven, S. (2010). İlköğretim hayat bilgisi dersi ders ve öğrenci çalışma kitaplarının öğretmen görüşlerine göre değerlendirilmesi. Eğitim ve Bilim, 35 (156), 84-95.

Harman, G., \& Çökelez, A. (2017). Öğretimde analoji kullanımının etkisi: lamba parlaklığını nasıl değiştirebiliriz? Necatibey Eğitim Fakültesi Elektronik Fen ve Matematik Eğitimi Dergisi, 12(1), 361-391.

Harrison, A. G., \& Treagust, D. F. (1993). Teaching with analogies: A case study in grade-10 optics. Journal of Research In Science Teaching, 30(10), 1291-1307.

Heywood, D. (2002). The place of analogies in science education. Campridge Journal of Education, 32 (2), 64-75.

Hıdır, M. \& Didiş Körhasan, N. (2018). Fen ders kitaplarındaki analojilerin ve fen eğitimcilerinin analojilerin etkili kullanımına ilişkin görüşlerinin incelenmesi. Necatibey Eğitim Fakültesi Elektronik Fen ve Matematik Eğitimi Dergisi, 12 (2).

İnal, N. \& Mentiş Taş, A. (2011). İlköğretim 3. sınıf hayat bilgisi ders kitaplarına ilişkin öğretmen görüşleri. Selçuk Üniversitesi Ahmet Keleşoğlu Eğitim Fakültesi Dergisi, (31), 279-295. 
A, Şeyihoğlu, İ. E., Özgürbüz \& E, Torun / Pamukkale University Journal of Education, 55, 347-375, 2022

Kaçar, T. \& Bulut, B. (2020). Sosyal bilgiler öğretim programı ve 4-7. sınıf sosyal bilgiler ders kitaplarının coğrafya kavramları bălamında değerlendirilmesi. Kahramanmaraş Sütçü İmam Üniversitesi Sosyal Bilimler Dergisi, 17(2), 652-679.

Kaptan, F. \& Arslan, B. (2002). Fen öğretiminde soru-cevap tekniği ile analoji tekniğinin karşılaştırılması. V. Ulusal Fen Bilimleri ve Matematik Eğitimi Kongresi, 183-189.

Karadeniz, S. (2017). Ortaokul matematik ders kitaplarında kullanılan analojilerin incelenmesi. (Yüksek lisans tezi). Yükseköğretim Kurulu Ulusal Tez Merkezi’nden edinilmiştir. (Tez No. 476119)

Karadüz, A. (2006). İlköğretim Türkçe dilbilgisi kitaplarının ‘öğreticilik’ kavramı bağlamında eleştirisi. Sosyal Bilimler Enstitüsü Dergisi, 2 (21), 13-31.

Karasu Avcı, \& Faiz, M. (2018). 4. ve 5. sınıf sosyal bilgiler ders kitapları "etkin vatandaşlık" öğrenme alanında yer alan becerilerin ve değerlerin incelenmesi. Uluslararası Sosyal Bilgilerde Yeni Yaklaşımlar Dergisi, 2(1), 1-21.

Kaya, E. (2010). Fen ve teknoloji ders kitaplarında ve ögretim programındaki benzetmelerin gruplandırılması. (Yüksek lisans tezi). Yükseköğretim Kurulu Ulusal Tez Merkezi'nden edinilmiştir. (Tez No. 259886).

Kaymakc1, S. (2013). Sosyal bilgiler ders kitaplariinda sözlü ve yaziilıi edebî türlerin kullaniim durumu. Dicle Üniversitesi Ziya Gökalp Eğitim Fakültesi Dergisi, (20), 230-255.

Kete, R. (2006). 6. sınıf fen bilgisi biyoloji konularında kavram yanılgıları. Dokuz Eylül Üniversitesi Buca Ĕ̈itim Fakültesi Dergisi, 19, 63-70.

Kırtak Ad, V. N., \& Tüfekçi, E. (2021). Ortaöğretim fizik ders kitaplarında yer alan analojiler: belirleme, sınıfiniflandirma ve karşılaştırma çalışması. International Journal of New Trends in Arts, Sports \& Science Education, 10(2), 130-144.

Kobak, R. (2013). Ortaöğretim kimya ders kitaplarında yer alan analojilerin analog-hedef haritalama yapılarının incelenmesi. (Yüksek lisans tezi). Yükseköğretim Kurulu Ulusal Tez Merkezi'nden edinilmiştir. (Tez No. 324650).

Kolaç, E. (2003). İlköğretim dördüncü sınıf Türkçe ders kitaplarının öğretmen görüşlerine dayalı olarak değerlendirilmesi. Uludă̆ Üniversitesi Eğitim Fakültesi Dergisi, 17 (1), 105-137. 
Köseoğlu, F., Atasoy, B., Kavak, N., Akkuş, H., Budak, E., Tümay, H., Kadayıfçı, H. \& Taşdelen, U. (2003). Bir fen ders kitabı nasıl olmalı. Ankara: Asil Yayın Dağıtım.

Köymen, Ü. (2000). Güdüleyici Öğrenme. (1.bs). A. Şimşek (Ed.). Sinıfta Demokrasi, içinde (s.111-145), Ankara: Eğitim Sen Yayınları.

Malatyalı, E. \& Yılmaz, K. (2010). Yapılandırmacı öğrenme sürecinde kavramlar ve önemi: Kavramların pedagojik açıdan incelenmesi. Uluslararası Sosyal Araştırmalar Dergisi, 3 (14), 320-332.

Milli Eğitim Bakanlığı, (2006). Mevzuat, ders kitapları ile eğitim araçlarının incelenmesi ve değerlendirilmesine ilişkin yönerge., Tebliğler Dergisi, Ekim.

Milli Eğitim Bakanlığı, (2012). Talim ve terbiye kurulu başkanlı̆̆ı, ilköğretim sosyal bilgiler ögretim programı (4. ve 5. sınıflar). Ankara: Milli Eğitim Bakanlığı.

Newton, L. D. (2003). The occurence of analogies in elementary school science books. Instructional Science, (31), 353-375.

Orgill, M. K. \& Bodner, G. M. (2006). An analysis of the effectiveness of analogy use in college-level biochemistry textbooks. Journal of Resarch In Science Teaching, 43 (10), 1040-1060.

Özay, E. \& Hasenekoğlu, İ. (2006). Biyoloji ders kitapları üzerine yapılan çalışmalar. Atatürk Üniversitesi Bayburt Ĕ̈itim Fakültesi Dergisi, 1 (1), 68-79.

Öztürk, F., N. \& Aydın, A. (2013). 7. sınıf fen ve teknoloji müfredat modülasyonu: öğretmenlerden gelen özgün anlamlar/analojiler. International Journal of Social Science, 6 (1), 299-309.

Reeves, T.C., Herrington, J.\& Oliver, R. (2002). Authentic activities and online learning. Proceedings of the 25th HERDSA Annual Conference, Perth, Western Australia, 710 July 562.

Schreglmann, S. (2019). Ortaöğretim bilgisayar bilimi ders kitabındaki analojilerin incelenmesi. İlköğretim Online, 18 (4), 1641-1651.

Senemoğlu, N. (2011). Gelişim öğrenme ve öğretim kuramdan uygulamaya. Ankara: Pegem A Yayıncilik. 
Şahin, F. (2010). Okul Öncesinde Kavram Haritalar1-Analojiler ve Deney, R. Zembat, (Ed.), Okul Öncesinde Özel Öğretim Yöntemleri, içinde (s. 285-314), Ankara: Anı Yayıncilik.

Şaşmaz Ören, F., Ormancı, Ü., Babacan, T., Çiçek, T. \& Koparan, S. (2010). Analoji ve araştırma temelli öğrenme yaklaşımına dayalı rehber materyal uygulaması ile buna yönelik öğrenci görüşleri. Batı Anadolu Ĕ̆itim Bilimleri Dergisi, 1 (1), 33-53.

Şeyihoğlu, A. \& Özgürbüz, İ. E. (2015). Analysis of analogies in geography textbooks. Education and $\quad$ Science. (40)179, 163-179. doi: http://dx.doi.org/10.15390/EB.2015.2609

Şeyihoğlu, A., Akbaş, Y., Kartal, A. (2012). Uygulama örnekleri ile coğrafya eğitiminde kavram ve zihin haritaları, Ankara: Pegem Akademi.

Şimşek, A. (2006). Kavramların öğretimi (1. bs.). A. Şimşek (Ed.), İ̧̧erik Türlerine Dayalı Öğretim, içinde (ss. 27- 70). Ankara: Nobel Yayıncılık.

Tezcan, H. \& Seyitoğlu, B. (2007). Lise kimya ders kitaplarının analojik açıdan incelenmesi. Milli Eğitim Dergisi, 36 (174), 282-292.

Thiele, R. B., \& Treagust, D. F. (1994). An interpretive examination of high school chemistry teachers' analogical explanations. Journal of Research in Science Teaching, 31(3), 227-242.

Thiele, R.B. \& Treagust, D. F. (1991). Using analogies to aid understanding in secondary chemistry education. Educational Resources Information, Center (ERİC).

Tufan, M. (2019). Kimya ders kitaplarındaki \& kimya öğretmenlerinin geliştirdikleri analojilerin incelenmesi. (Yüksek lisans tezi). Yükseköğretim Kurulu Ulusal Tez Merkezi'nden edinilmiştir. (Tez No. 583568).

Türk, M. S. \& Dursun, B. (2006). MEB tarafindan ortaöğretim kurumlarında okutulan ders kitaplarının biçimsel açıdan incelenmesi. Atatürk Üniversitesi Bayburt Ĕ̈itim Fakültesi Dergisi, 1(1), 20-36.

Ülgen, G. (2001). Kavram geliştirme. Ankara: Pegem A Yayıncılık.

Yıldırım, A. \& Şimşek, H. (2016). Sosyal bilimlerde nitel araştırma yöntemleri. Ankara: Seçkin Yayıncılı. 
Yılmaz, K. \& Çeltikçi, C. (2013). İlköğretim 3. sınıf öğrencilerine soyut ve çok boyutlu kavramların kazandırılması: Bir eylem araştırması. Turkish Studies-International Periodical for the Languages, Literature and History of Turkish or Turkic, 8(6), 895924. 